\title{
Financial Services and Trade Agreements in Latin America and the Caribbean: An Overview
}

by

\section{MARILYNE PEREIRA GONCALVES AND CONSTANTINOS STEPHANOU*}

\begin{abstract}
The objective of this paper is to briefly review the international framework governing trade in financial services, to describe the treatment of financial services in recent trade agreements involving Latin America and Caribbean countries, and to analyze the liberalization commitments made in three selected country case studies (Chile, Colombia and Costa Rica). Emphasis is given to free trade agreements because of the generally deeper level of liberalization and rule-making achieved to-date. The authors discuss some of the causes and potential implications of their findings.
\end{abstract}

Keywords: Chile, Colombia, Costa Rica, trade agreements, financial services, GATS.

World Bank Policy Research Working Paper 4181, April 2007

The Policy Research Working Paper Series disseminates the findings of work in progress to encourage the exchange of ideas about development issues. An objective of the series is to get the findings out quickly, even if the presentations are less than fully polished. The papers carry the names of the authors and should be cited accordingly. The findings, interpretations, and conclusions expressed in this paper are entirely those of the authors. They do not necessarily represent the view of the World Bank, its Executive Directors, or the countries they represent. Policy Research Working Papers are available online at http://econ.worldbank.org.

\footnotetext{
* Marilyne Pereira Goncalves (mgoncalves2@worldbank.org) is a consultant in the World Bank’s Financial Market Integrity department and Constantinos A. Stephanou (cstephanou@worldbank.org) is a Financial Economist in the World Bank's Latin America and the Caribbean Region. This paper forms part of a broader project on trade in financial services in Latin America and the Caribbean Region. The authors would like to thank Pierre Sauvé for his excellent guidance, and express their gratitude to Augusto de la Torre, Carsten Fink, Juan Marchetti and Latifah Osman Merican for helpful comments and suggestions.
} 


\section{Table of Contents}

I. INTRODUCTION

II. OVERVIEW OF TRADE IN FINANCIAL SERVICES ..................................5

Liberalization of Trade in Financial Services Vs. Financial Liberalization ................... 5

Multilateral Framework for Trade in Financial Services ............................................. 6

GATS Commitments in Financial Services ............................................................... 12

III. FINANCIAL SERVICES IN LCR TRADE AGREEMENTS ...........................15

Overview of Preferential Trade Agreements in LCR ............................................... 15

Treatment of Financial Services ............................................................................... 19

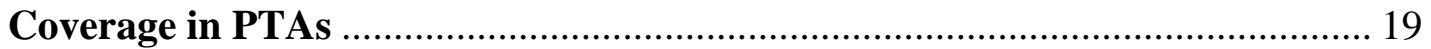

Competing Liberalization Models (NAFTA versus GATS) .................................. 23

Financial Services-Related Rules and Disciplines ..................................................... 26

IV. ANALYSIS OF FINANCIAL SERVICES COMMITMENTS ..........................31

Comparison to GATS ........................................................................................... 31

Comparison to the Status Quo (Unilateral Liberalization) ........................................... 35

V. CONCLUSION

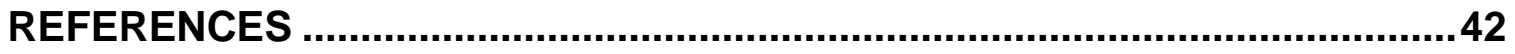

APPENDIX I: GATS DEFINITION OF FINANCIAL SERVICES ......................45

APPENDIX II: LIBERALIZATION COMMITMENTS IN FINANCIAL SERVICES

FOR SELECTED LCR COUNTRIES .............................................................47 


\section{List of Tables}

Table 1: GATS Framework on Financial Services ......................................................... 9

Table 2: Sample Schedule of Financial Services Commitments ........................................ 11

Table 3: Coverage and Treatment of Financial Services in LCR PTAs (as of mid-2006) 17

Table 4: Coverage of Financial Services (FS) by Type of FTA in LCR ........................... 39

Table II-1: Chile - Financial Services Trade Liberalization Commitments...................... 47

Table II-2: Colombia - Financial Services Trade Liberalization Commitments............... 49

Table II-3: Costa Rica - Financial Services Trade Liberalization Commitments ............. 50

\section{List of Figures}

Figure 1: Composition of Financial System Assets (1995-2005) .................................... 13

Figure 2: ‘Map’ of Financial Services-Related Trade Commitments in LCR (mid-2006)20

Figure 3: Financial Services Trade Balance for Selected LCR Countries (1997-2004)... 22

Figure 4: Foreign Bank Penetration in Selected LCR Countries..................................... 22

Figure 5: Proportion of Financial Services Sub-Sectors Committed by Chile, Colombia and Costa Rica in the GATS and in Subsequent FTAs ............................................ 34

Figure 6: Market Share of Foreign Financial Institutions in the Domestic Financial Systems of Chile, Colombia and Costa Rica at the Time of FTA Negotiations........ 37

Figure 7: International Financial Integration of Chile, Colombia and Costa Rica (19972004)

\section{List of Boxes}

Box 1: Collective Request in Financial Services 


\section{Introduction}

International trade in financial services represents an increasingly important dimension of domestic financial activities and a manifestation of recent trends in globalization and the application of information technology that have vastly increased the integration of markets worldwide. There are typically three ways in which the liberalization of financial services trade can be achieved. First, it can be done unilaterally when countries decide to open their financial systems to international competition, typically in the context of far-reaching autonomous domestic reform efforts. Secondly, it can take the form of specific trade commitments at the multilateral level under the auspices of the World Trade Organization (WTO). Finally, countries can enter in preferential trade agreements (PTAs), either bilateral or plurilateral, where the removal of barriers to trade and investment is negotiated on a reciprocal and preferential basis.

The objectives of this paper are threefold: (1) to briefly review the international framework governing cross-border trade and investment in financial services; (2) to describe the treatment of financial services in PTAs by countries in the Latin America and Caribbean region (LCR); and (3) to analyze and compare the liberalization commitments made in the financial services chapters of selected PTAs for three LCR countries (Chile, Colombia and Costa Rica). Although PTAs in the LCR comprise free trade agreements (FTAs, e.g. NAFTA) and customs unions (e.g. MERCOSUR), the paper devotes particular attention to the former because of the generally deeper level of financial services liberalization and rule-making achieved to-date under such agreements. Given the broad scope of this exercise, the paper does not provide an in-depth analysis of the multilateral trading framework and of non-financial services-related aspects of PTAs, or speculate on the implications of the proliferation of such trade agreements for the multilateral trading system and on their impact on domestic financial systems.

The paper is structured as follows:

- Section II briefly describes trade in financial services and the framework of rules governing such trade at the multilateral level;

- Section III provides an overview of PTAs in LCR and their treatment of financial services in terms of coverage, template and disciplines;

- Section IV compares financial services commitments in selected PTAs to LCR countries' prior multilateral commitments and to unilateral liberalization efforts;

- Section V summarizes the paper's main findings and related policy implications, and identifies potential follow-up research topics going forward. 


\section{Overview of Trade in Financial Services}

\section{Liberalization of Trade in Financial Services Vs. Financial Liberalization}

In contrast to trade in goods, the main barriers to international trade in financial services are "behind-the-border" domestic non-tariff measures (i.e. laws, regulations and administrative procedures) that impede access to markets by, or take the form of discriminatory treatment of, foreign financial service providers. As regards the domestic presence of foreign service providers, examples of potential impediments include differential taxation rates and unduly onerous prudential regulations (e.g. licensing requirements), as well as restrictions on their entry and on foreign equity participation in existing domestic financial institutions, restrictions on the location of branches and the scope of operations, or on the value of transactions or assets ${ }^{1}$. Barriers to cross-border trade in financial services include the prohibition for consumers to purchase financial services abroad and on services being supplied remotely by non-established foreign providers. The lifting of such barriers, which impede the ability of foreign financial services providers to be placed on an equal competitive footing with domestic suppliers, is what is typically understood by the liberalization of trade in financial services.

In addition to the direct barriers to international trade in financial services that are usually explicitly discriminatory, there also exists a continuum of non-discriminatory barriers whose adverse effects are typically implicit and unintentional. Such indirect barriers include those related to the co-existence of diverse national laws and regulatory standards and practices which - in the absence of regulatory harmonization or mutual recognition - may raise the cost of regulatory compliance and of doing business for foreign providers (home and host country regulatory burden). The latter measures are often justified on the basis of the overarching objective of protecting the stability and integrity of domestic financial systems, even though the development and adoption of international standards and codes ('soft laws') by multilateral organizations ${ }^{2}$ have facilitated the process of regulatory convergence with respect to the prudential oversight of financial markets. Indeed, some commentators have argued that the gains arising from trade liberalization in financial services greatly depend on the quality of domestic regulation and of the broader institutional environment (e.g. disclosure and transparency practices, rule of law etc. $)^{3}$. As discussed later in the paper, there is some uncertainty as to where discrimination 'stops', i.e. where the line is (or should be) drawn between tradedistorting measures and domestic regulation. It should be noted that international trade agreements ('hard law') have primarily focused to-date on market access-impeding and discriminatory barriers to trade in financial services, although they have also contributed to the reduction of non-discriminatory barriers via, for example, greater regulatory transparency and commonly accepted dispute settlement mechanisms.

\footnotetext{
${ }^{1}$ See Sauvé P. and Steinfatt K. (2001) for country-specific examples of barriers to financial services trade.

${ }^{2}$ International standard-setters include, among others, the World Bank, the IMF, the Basel Committee on Banking Supervision, the International Association of Insurance Supervisors, the IOSCO and the OECD.

${ }^{3}$ See, for example, Claessens S. (July 2002).
} 
An important conceptual distinction needs to be drawn between trade policy reform in financial services and financial liberalization ${ }^{4}$. The purpose of the former is to increase financial market access and remove discriminatory and other access-impeding barriers to foreign competition. By contrast, the chief purpose of financial liberalization is to remove distortions in domestic financial systems - for example, interest rate and capital account controls, directed lending policies, restrictions on intra-sectoral activities, preferential treatment of publicly-owned banks, entry barriers for new operators - that impede competition and the allocation of capital to its most productive and profitable uses. Financial liberalization can be further divided into domestic financial reform and capital account opening, and there is a broad literature on its appropriate speed and sequencing 5 . In that context, the liberalization of trade in financial services is a subset of the broader financial liberalization agenda. A country may thus not directly discriminate against foreign financial service providers while still operating a repressed financial system. Conversely, a country may decide to engage in partial, pro-competitive regulatory reform in its domestic financial market, but keep it closed to foreign competition.

In practice, however, there are typically strong overlaps between the two types of policy reforms described above. Trade in financial services is often linked to capital movements, notably in the context of the establishment of a commercial presence which requires inward direct investment. Certain types of cross-border financial transactions may also involve capital movements and hence require some measure of capital account opening as an inherent part of the service provision ${ }^{6}$. In addition, countries often seek to promote greater policy coherence by opening up domestic financial markets to foreign competition in the context of broader financial reform efforts. Finally, it bears noting that neither the liberalization of trade in financial services nor financial liberalization imply the complete deregulation of the domestic financial system per se. Quite the contrary, experience shows that stronger regulatory and supervisory frameworks are key complements to market opening measures so as to ensure that consumers and depositors are properly protected and that the integrity of the financial system and its ability to discharge its critical economy-wide functions are properly preserved.

\section{Multilateral Framework for Trade in Financial Services}

The WTO's General Agreement on Trade in Services (GATS) represents the only legally binding framework of rules governing trade in services at the multilateral level ${ }^{7}$. The Agreement consists of three core elements (see Table 1 below):

\footnotetext{
${ }^{4}$ See Claessens S. and Glaessner T. (April 1998), and Claessens S. and Jansen M. (2000) for a comprehensive discussion.

${ }^{5}$ See, for example, Demirguc-Kunt A. and Detragiache E. (June 1998), Johnston B. (July 1998) and Kaminsky G. and Schmukler S. (February 2003).

${ }^{6}$ See OECD (March 2000) and Tamirisa N. et al. (February 2000) for a classification of financial service transactions into those that are not accompanied by underlying capital movements (e.g. consulting, advisory and information services), those that are inseparable from capital flows (e.g. cross-border lending), and those that may involve a capital movement (e.g. asset management, insurance).

${ }^{7}$ Strictly speaking, the OECD's Code of Liberalization of Capital Movements (which also covers direct investment and establishment) and Code of Liberalization of Invisible Operations (which covers services),
} 
- The GATS framework, which spells out the Agreement's substantive disciplines

- The schedules of commitments of WTO Members that describe the nature, extent and timing of market opening undertakings, including any limitations or exceptions thereto

- 12 Annexes, which include additional or clarifying rules on specific sectors, including financial services.

The GATS specifically excludes any "services supplied in the exercise of governmental authority" ${ }^{8}$ and defines trade in services - including financial services - as consisting of four modes of supply:

- cross-border supply (mode 1), e.g. foreign providers supply a domestic market remotely

- consumption abroad (mode 2), e.g. domestic consumers purchase financial services abroad (e.g. while traveling abroad)

- commercial presence (mode 3), e.g. the physical establishment of a foreign provider via a subsidiary, branch or representative office for purposes of selling services in a host country market

- temporary presence of natural persons (mode 4), e.g. the temporary entry of foreign individuals for purposes of selling financial services to host country consumers or as key personnel working for a foreign-established firm in the host country market (so-called intra-company transferees).

Even though commercial presence (mode 3) is considered to be the principal means of financial services delivery, especially for retail customers where physical contact is generally required ${ }^{9}$, the cross-border provision of services is becoming increasingly important in view of increased worldwide travel and e-commerce developments. In fact, the advent of e-finance has introduced additional complications to the above framework, since it is not always clear whether the online provision of financial services by foreign providers belongs to modes 1 or $2^{10}$. By contrast, mode 4 is relatively less important in financial services as it is severely constrained by receiving countries' migration policies and chiefly relates to highly-skilled experts or intra-company transferees in managerial positions. It should also be noted that the above nationality-based definition of services trade is significantly broader than the one used for balance of payments purposes, which is based on the principle of residency; this difference arises primarily from the fact that trade in services under GATS includes the movement of both capital and labor.

which have been in existence since the 1960's, are earlier examples of binding legal instruments for promoting progressive liberalization among OECD Member governments. However, they are not a treaty or international agreement in the sense of international law, as is the case for WTO agreements.

${ }^{8}$ The definition of governmental authority for financial services is described later in this section.

${ }^{9}$ According to Harms P., Mattoo A. and Schuknecht L. (March 2003) who estimated the relative size of different modes and sub-sectors in financial services based on US data, "establishment trade is three-and a half times greater than cross-border trade for imports and more than twice as large for exports."

${ }^{10}$ Although there are no universally agreed upon criteria, some WTO Members have based the distinction between modes 1 and 2 on whether there are one or two jurisdictions involved in the provision of a financial service and whether the service was provided as a result of direct online, cross-border solicitation. 
The GATS framework features a set of general obligations applicable to all services sectors regardless of the level of specific commitments of individual WTO Members. The most important ones are:

- most-favored-nation (MFN) treatment (Article II), which requires extending liberalization measures in a sector to all WTO Members equally on the principle of non-discrimination ${ }^{11}$

- transparency (Article III) with respect to the prompt publication, notification and inquiries response by Members of relevant measures ${ }^{12}$ (and their changes) and international agreements that affect trade in services covered by their GATS commitments

An important exception to GATS principles is found in article XII of the GATS concerning restrictions on trade in services commitments in order to safeguard the balance of payments. The latter are allowed under the GATS so long as they are proportional in scope, non-discriminatory, consistent with the IMF's Articles of Agreement and temporary in nature.

The GATS stipulates that Members undertake specific commitments in their schedules on market access (i.e. elimination of quantitative or juridical barriers to entry; Article XVI)) and national treatment (i.e. non-discrimination between domestic and foreign providers; Article XVII $)^{13}$. While the Agreement does not define market access, it lists six types of restrictions that a Member cannot impose (unless inscribed in its schedule): on the number of service suppliers, the value of service transactions or assets, the number of operations or quantity of output, the number of natural persons supplying a service, the type of legal entity, and the participation of foreign capital. By contrast, there is no comparable typology for national treatment restrictions, so it is up to individual Members to ensure that all potentially relevant measures are listed in sectors where commitments are scheduled. Members may also schedule additional commitments under Article XVIII, such as those regarding qualifications, standards or licensing matters.

Finally, with regards to institutional provisions, covered measures are subject to both a consultation and a dispute settlement mechanism common to both goods and services trade under the WTO. Members may use the latter to initiate an arbitration procedure to enforce the (legally binding) commitments undertaken by another Member, which can ultimately result in trade sanctions equal to the commercial loss arising from the continued maintenance of a measure found in breach of the violating country's commitments.

The GATS contains specific provisions on financial services, which are included in the Financial Services Annex (FSA). The FSA defines financial services as "any service

\footnotetext{
${ }^{11}$ Permissible departures from MFN obligations include one-time exemptions (usually based on preexisting reciprocity provisions) taken upon entry into force of a country's initial schedule of commitments, economic integration agreements (to the extent that they do not result in a more restrictive market access situation for services suppliers from countries outside such agreements) and prudential standards.

${ }^{12}$ Such measures include laws, regulations, rules, procedures, decisions and administrative actions.

${ }^{13}$ In contrast to the trade agreement on goods (GATT), national treatment is not a general obligation in the GATS because it would have meant that granting market access would be the equivalent of establishing free trade, while governments wanted to proceed more gradually in opening up their services markets.
} 
of a financial nature offered by a financial service supplier ${ }^{14}$ of a Member. Financial services include all insurance and insurance-related services, and all banking and other financial services (excluding insurance)" (see Appendix I for a detailed description). The Annex specifically excludes "(i) activities conducted by a central bank or monetary authority or by any other public entity in pursuit of monetary or exchange rate policies; (ii) activities forming part of a statutory system of social security or public retirement plan; and (iii) other activities conducted by a public entity for the account or with the guarantee or using the financial resources of the Government"15. This implies that macroeconomic management and a potentially significant part of the financial sector (e.g. development banks, mandatory pension funds that form part of the social security system in many LCR countries etc.) are not subject to WTO disciplines.

Table 1: GATS Framework on Financial Services

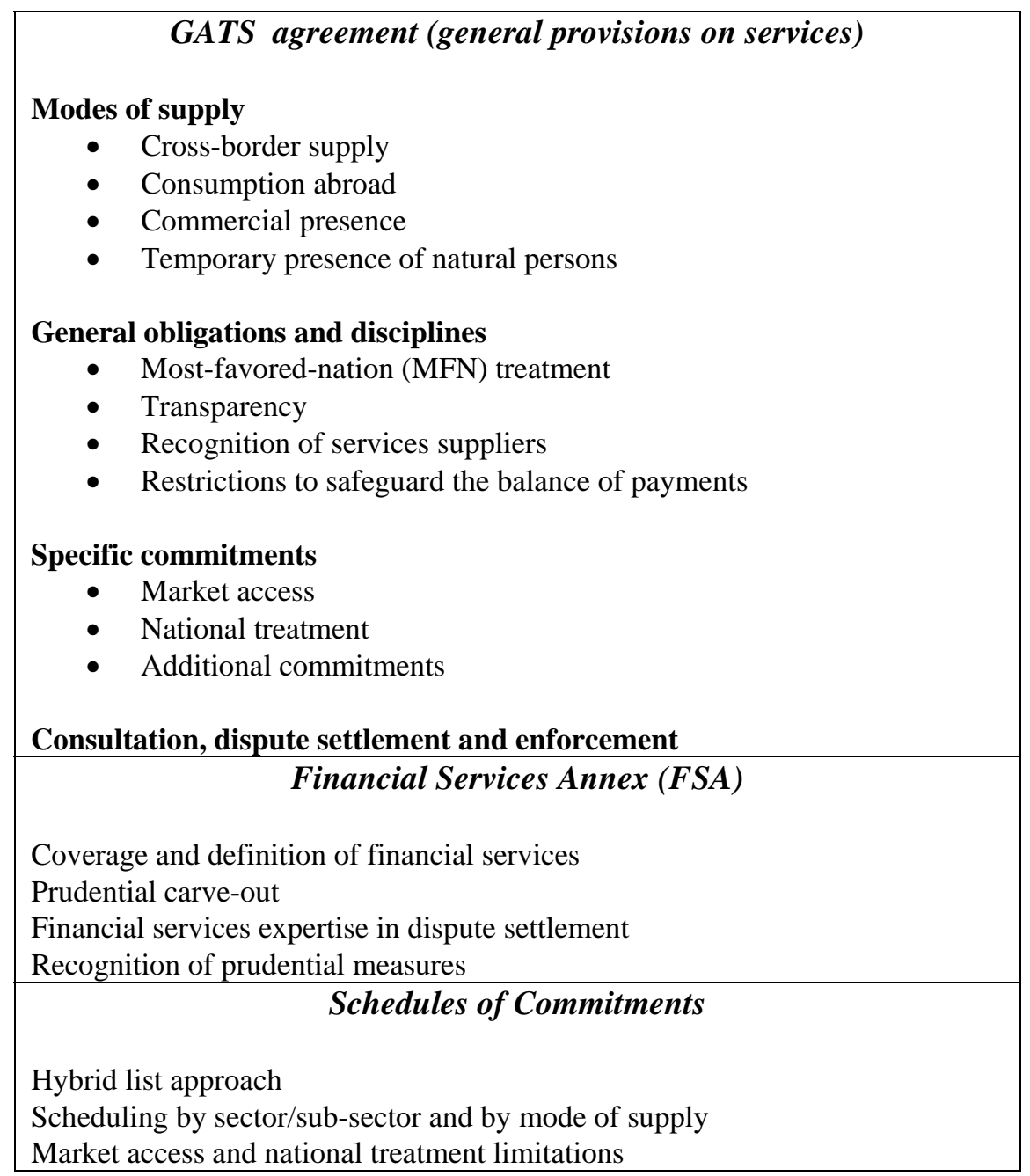

Source: Adapted from Key S. (1997).

\footnotetext{
${ }^{14}$ A financial service supplier is defined as "any natural or juridical person of a Member wishing to supply or supplying financial services”, excluding public entities.

15 If a Member allows any of activities (ii) or (iii) to be conducted by its financial service suppliers in competition with a public entity or a financial services supplier, "services” shall include these activities.
} 
The Annex is also important because it includes a "prudential carve out" clause that recognizes the right of WTO Members to introduce and maintain prudential measures "including for the protection of investors, depositors, policy holders or persons to whom a fiduciary duty is owed by a financial service supplier, or to ensure the integrity and stability of the financial system". Such a right is not absolute under GATS, as such measures are subject to dispute settlement if they are used as a disguised restriction to trade or investment with a view to nullifying and/or impairing the scheduled liberalization commitments of WTO Members ${ }^{16}$. However, the FSA provides no definition or indicative list of prudential measures, affording domestic financial regulators broad discretion in their choice of prudential conduct so long as measures are not applied for protectionist purposes. It need be recalled that in its Preamble, the GATS explicitly recognizes the right of member states, and especially of developing countries, to regulate the supply of services within their territories in order to pursue national policy objectives, as well as to conduct negotiations on the basis of progressive liberalization. In fact, the GATS does not preclude any particular form of government involvement in the domestic financial system, such as directed or preferential lending schemes, as long as it is non-discriminatory in nature and is administered transparently and objectively.

Following protracted negotiations held after the Uruguay Round's conclusion, a new set of specific commitments on financial services was incorporated to the GATS in the $5^{\text {th }}$ Protocol of December 1997. Such commitments entered into force in March $1999^{17}$. Over 100 WTO Members undertook legally binding commitments on market access and national treatment in the FSA ${ }^{18}$. The specific commitments of WTO Members take two forms - horizontal (i.e. applicable to all sectors in a schedule) and sector-specific - and relate to any of the four modes of supply. Specific commitments range from full liberalization (meaning that no limitations to market access and/or national treatment are maintained in a particular sector/sub-sector or mode of supply) to full discretion to apply new restrictive measures in the future; under GATS, the latter may take the form either of no commitments or, in sectors or sub-sectors subject to specific commitments, to "unbound commitments" affecting individual modes of supply (see Table 2 below).

GATS commitments are scheduled on the basis of a so-called "hybrid" list approach, which combines elements of 'positive' or 'bottom up' listing (i.e. identifying the sectors and/or modes of supply concerned) and 'negative' or 'top down' listing (i.e. identifying the limitations and restrictions attached to specific commitments) ${ }^{19}$.

\footnotetext{
16 This prudential clause has not yet been tested in dispute settlement and its coverage is still uncertain, especially since countries may have different perceptions on this issue for historical reasons. For example, European countries with a universal banking tradition could argue that traditional line-of-business restrictions (i.e. separation of banking, securities and insurance) cannot be justified on prudential grounds.

${ }^{17}$ For a summary of this framework, see Kireyev A. (August 2002) and Tamirisa N. et al. (February 2000).

${ }^{18}$ Within LCR, Brazil and Jamaica have not yet ratified the fifth protocol to the GATS, so their current commitments are those dating back to the Uruguay Round.

${ }^{19}$ See section III for a fuller description of scheduling techniques.
} 
Table 2: Sample Schedule of Financial Services Commitments

\begin{tabular}{|c|c|c|c|}
\hline Sector or sub-sector & Limitations on market access & $\begin{array}{c}\begin{array}{c}\text { Limitations on national } \\
\text { treatment }\end{array} \\
\end{array}$ & $\begin{array}{c}\text { Additional } \\
\text { commitments }\end{array}$ \\
\hline \multicolumn{4}{|c|}{ I. HORIZONTAL COMMITMENTS } \\
\hline $\begin{array}{l}\text { All sectors included in } \\
\text { this schedule }\end{array}$ & $\begin{array}{l}\text { (4) Unbound, other than for } \\
\text { temporary presence, as intra- } \\
\text { corporate transferees, of essential } \\
\text { senior executives and specialists }\end{array}$ & $\begin{array}{l}\text { (3) Foreign investors may } \\
\text { transfer their capital } \\
\text { abroad three years after } \\
\text { from the date of entry }\end{array}$ & \\
\hline \multicolumn{4}{|c|}{ II. SECTOR-SPECIFIC COMMITMENTS } \\
\hline \multicolumn{4}{|l|}{ FINANCIAL SERVICES } \\
\hline \multicolumn{4}{|c|}{ Banking and Other Financial Services (excl. Insurance) } \\
\hline $\begin{array}{l}\text { Acceptance of deposits } \\
\text { and other repayable } \\
\text { funds from the public }\end{array}$ & $\begin{array}{l}\text { (1) Unbound. } \\
\text { (2) None. } \\
\text { (3) Foreign equity participation } \\
\text { limited to } 51 \text { percent. } \\
\text { (4) Unbound, except as indicated } \\
\text { in horizontal section. }\end{array}$ & $\begin{array}{l}\text { (1) Unbound. } \\
\text { (2) Unbound. } \\
\text { (3) None. } \\
\text { (4) Unbound, except as } \\
\text { indicated in } \\
\text { horizontal section. }\end{array}$ & \\
\hline
\end{tabular}

Note: (1) - (4) above refers to limitations on liberalization commitments in the 4 modes of supply. "None" and "unbound" refer to full and no liberalization commitment respectively for a specific mode.

In addition to the general and specific commitments undertaken in the GATS and the FSA, a group of mostly developed WTO Members ${ }^{20}$ agreed to subscribe to a higher level of commitments on trade in financial services by making use of the Understanding on Commitments in Financial Services, an alternative 'formula' schedule that was developed during the negotiations but remains voluntary in character. Members making use of the Understanding opt for an alternative approach to scheduling commitments that aims to achieve deeper liberalization across a wider menu of issues in financial services by relying exclusively on a negative list approach. Some of the main provisions of the Understanding are the following ${ }^{21}$ :

- $\quad$ standstill obligation, i.e. Members cannot introduce any new non-conforming measures that are incompatible with their liberalization commitments

- specific (and more liberal) market access commitments by mode of supply, including for cross-border trade

- extended scope of market access commitments to include monopoly rights, new financial services ${ }^{22}$, and financial services purchased by public entities

- extended scope of national treatment commitments to include access to payment and clearing systems operated by public entities, to "normal” official funding and refinancing (but not lender-of-last-resort) facilities, and to any self-regulatory body, securities or futures exchange or market etc.

- a "best efforts" commitment by Members to "endeavor" to remove or limit any adverse effects stemming from non-discriminatory measures (e.g. those

\footnotetext{
${ }^{20}$ No LCR countries have yet signed on to the Understanding, which represents one of the most frequent requests made by developed countries in the current round of multilateral trade negotiations.

${ }^{21}$ See OECD (November 2003) for a detailed description.

${ }^{22}$ This is defined as " a service of a financial nature, including services related to existing and new products or the manner in which a product is delivered, that is not supplied by any financial service supplier in the territory of a particular Member but which is supplied in the territory of another Member".
} 
related to differences in regulatory regimes) that might impede the ability of other Members' suppliers to operate, compete or enter the Member’s market.

\section{GATS Commitments in Financial Services}

In terms of the overall number of scheduled commitments, financial services ranks second in importance in the GATS behind tourism ${ }^{23}$. Commitments tend to be of three types when compared to Members' regulatory situation prevailing at the time of the agreement's entry into force. Firstly, a few countries made use of the GATS to precommit to future liberalization in order to lend credibility to and 'lock in' recent reform measures, as well as to allow domestic firms to prepare for future competition. Secondly, a large number of Members, particularly OECD Member countries, have bound the regulatory status quo in their GATS schedules, consolidating the actual degree of openness (or restrictiveness) prevailing at the time of the FSA's entry into force ${ }^{24}$. Finally, anecdotal evidence suggests that many Members, particularly developing countries, opted to bind commitments below the regulatory status quo ${ }^{25}$. Of course, these three types of commitments are not mutually exclusive and individual countries may have pursued different approaches depending on the sub-sector and mode of supply.

Although binding commitments can be argued to help 'lock in' reforms and enhance their credibility while also improving host country investment climates, ${ }^{26}$ a number of reasons can be offered to explain the reluctance of some WTO Members to take on binding commitments in financial services. These include macroeconomic and regulatory weaknesses as well as strategic motivations (e.g. membership of preferential trade groups). In addition, the fact that the FSA was completed after the end of the Uruguay Round turned financial services into a single-sector negotiation and may have provided incentives to developing countries with limited export interests in financial services to limit policy bindings in order to use them as future negotiating chips.

With respect to market access and national treatment commitments in different modes of supply, various studies have shown that commitments in modes 1 and 2 have been relatively timid compared to those for mode 3, while developing countries have generally made fewer overall commitments ${ }^{27}$. Compared to other regions, LCR countries were among the most reluctant to open their financial services sectors and made relatively few commitments. The latter were mostly focused on mode 3 (see Figure 1), but with market

\footnotetext{
${ }^{23}$ See Marchetti J. (September 2004) for more details.

${ }^{24}$ However, some countries - including Colombia, Honduras, Peru and Venezuela in LCR - maintained MFN exemptions in their financial services schedules, which state that (additional) market access may be granted on a reciprocal basis.

${ }^{25}$ In those countries - including Brazil in LCR - where policy regimes could or had become more restrictive compared to the time when foreign firms first entered, grandfathering provisions were used to guarantee the privileges of incumbents while making below 'status quo' commitments on commercial presence for new entrants.

${ }^{26}$ This, for example, seems to have been the case for Argentina's (extensive) financial services commitments in the GATS - see Bouzas R. and Soltz H. (December 2005).

${ }^{27}$ See Mattoo A. (September 1999) for an analysis of liberalization commitments in financial services.
} 
access restrictions such as the maintenance of an economic needs test or limitations on the juridical form of establishment. The lack of commitments in mode 1 (as well as in mode 2 for some countries) predominantly relates to prudential concerns, i.e. the reluctance of Members to take on legally binding commitments that might require concomitant capital account opening measures (thereby introducing volatile capital flows $)^{28}$. Such reluctance may also reflect concerns over jurisdictional uncertainties that could complicate regulatory control and financial supervision, although there may have been some consumer protection concerns as well.

Figure 1: Composition of Financial System Assets (1995-2005)

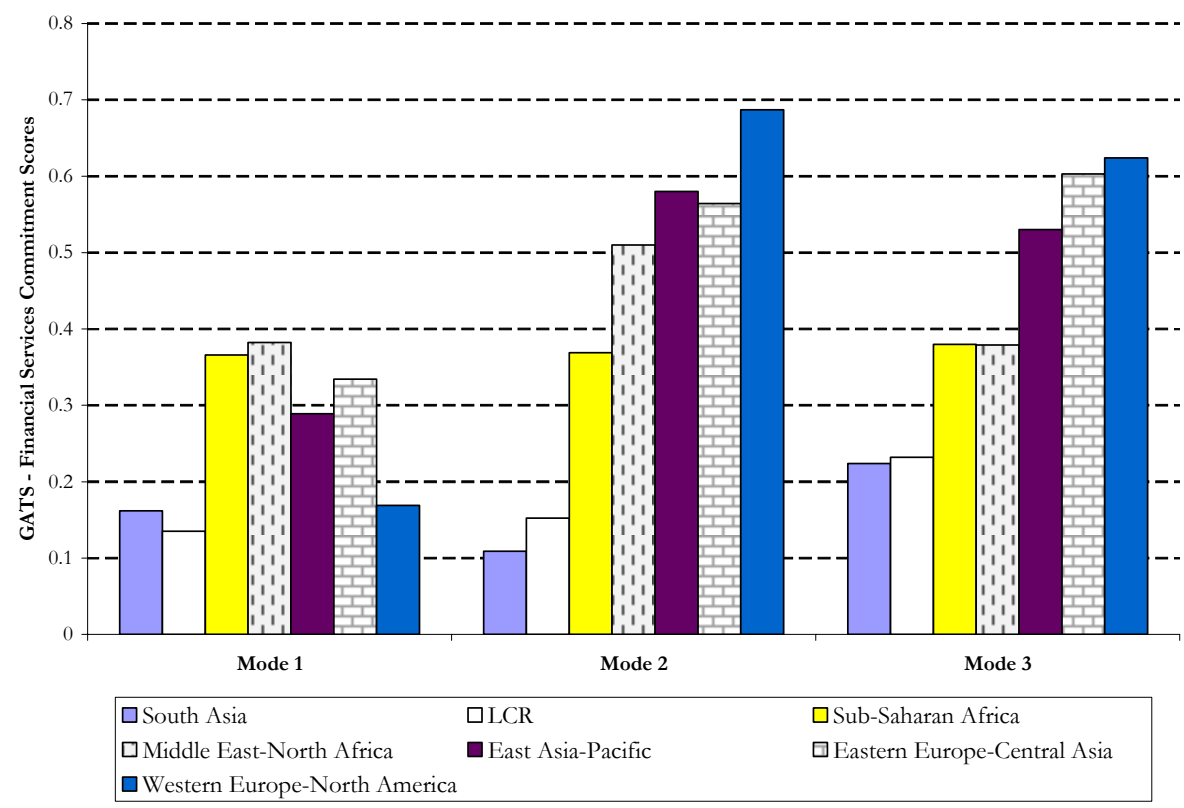

Source: Adapted from Valckx N. (October 2002).

Note: These represent average market access commitments by regional groupings (unweighted by size of country). See Valckx N. (October 2002) for a description of the methodology used to assign scores.

An analysis of liberalization commitments in financial services undertaken by countries in the GATS should be viewed with caution for at least two reasons: (1) commitments do not always reflect the actual degree of liberalization prevailing at that time; (2) modes and sub-sectors differ substantially in size within and across countries, which limits the usefulness of tables or liberalization indices that - without including any weights of relative importance - compare the number of sub-sectors in which

\footnotetext{
${ }^{28}$ GATS commitments do not directly oblige Members to open up their capital accounts. However, if a Member undertakes a market access commitment for mode 1 and if the cross-border movement of capital is an essential part of the service itself, then that Member is thereby committed to allow the relevant capital flow; the same applies for mode 3 commitments, but only for related capital inflows. Members do not have any obligations with respect to capital flows related to consumption abroad (mode 2). See Kono M. and Schuknecht L. (November 1998) for empirical analysis in support of proceeding more cautiously with mode 1 liberalization commitments in countries with weak financial systems.
} 
commitments were made. In fact, the measurement of both trade in financial services and of the actual level of restrictiveness remains an important on-going challenge ${ }^{29}$.

A new round of services negotiations began in January 2000 alongside those on agriculture as mandated by the Uruguay Round's built-in agenda. Both sets of negotiations were subsequently woven into the Doha Development Agenda (DDA) launched in November 2001. Some of the financial services-related issues under discussion in the DDA include the clarification in the scope of the FSA's prudential carve-out clause and of distinctions across modes relating to the electronic delivery of financial services, the expansion and strengthening of commitments on national treatment and market access across modes, as well as improved regulatory transparency and procedural fairness, particularly in matters of licensing ${ }^{30}$. Although the negotiations have been suspended, a collective request in financial services coordinated by Canada and cosponsored by several countries ${ }^{31}$ was lodged in early 2006 and could become a focal point going forward, assuming that negotiations resume (see Box 1 for a summary).

\section{Box 1: Collective Request in Financial Services}

- Definitions: Use the agreed definitions in the GATS Annex on Financial Services for scheduling commitments.

- Mode 1: undertake commitments for marine, aviation and transport insurance; reinsurance; insurance intermediation, insurance auxiliary services; financial advisory services and financial information and data processing services.

- Mode 2: undertake commitments for marine, aviation and transport insurance; reinsurance; insurance intermediation, insurance auxiliary services; and all non-insurance financial services (sub-sectors v-xvi).

- Modes 1 and 2: there can be advantages of additional liberalization, especially where the consuming agent is sophisticated, for example, an institutional consumer of securities services.

- Mode 3: for all financial services sectors, undertake commitments encompassing rights to establish new and acquire existing companies, in the form of wholly-owned subsidiaries, joint ventures and branches.

- Modes 1, 2 and 3: remove discrimination between domestic and foreign suppliers regarding application of laws and regulations ("national treatment").

- Modes 1, 2 and 3: remove limitations such as monopolies, numerical quotas or economic needs tests and mandatory cessions.

- Transparency in development and application of laws and regulations, transparent and speedy licensing procedures, and other regulatory issues should be addressed in the negotiations.

Source: Coalition of Service Industries (http://www.uscsi.org/publications/papers/collective/financial.pdf)

\footnotetext{
${ }^{29}$ Conventional trade statistics generally cover cross-border financial service transactions (mostly mode 1 ) but do not adequately capture commercial presence (mode 3). In addition, countries use different subsectoral classifications of financial services, such as the so-called W/120 classification based on the provisional UN Central Product Classification (CPC), the FSA classification, or a national classification see World Trade Organization (December 1998) for a discussion.

${ }^{30}$ See Sauvé P. and Steinfatt K. (2001), Dobson W. (August 2002), Key S. (2003) and Cornford A. (June 2004) for a discussion.

${ }^{31}$ It bears noting that only one LCR country - Ecuador - ranks among demandeur countries, whereas three countries from the region - Argentina, Brazil and Costa Rica - are targeted by this request.
} 


\section{Financial Services in LCR Trade Agreements}

\section{Overview of Preferential Trade Agreements in LCR}

There are different types of preferential trade agreements based on their level of economic integration, ranging from FTAs to custom unions and common markets. These agreements all have in common the objective of reducing or eliminating most duties and other barriers to trade and investment among Members. However, compared to FTAs, Members to customs unions also adopt common external tariffs and more generally a common trade policy vis-à-vis non-Members, while Members to common markets allow for the free movement of all factors of production between them. The highest degree of economic integration is found in economic unions that, in addition to a common trade policy and the free movement of factors of production, aim for the unification of economic policies and the adoption of a common currency among participating members.

Since the 1990s, the world economy has witnessed an unprecedented proliferation of PTAs. The WTO expects the number of such agreements to soon reach 300 if all negotiations currently underway are concluded; this compares to only 50 such PTAs worldwide as recently as $1990^{32}$. Although trade rules on services are more recent, WTO notifications for services agreements have grown at a very fast pace. Almost every WTO Member is party to at least one PTA, while some regions - including LCR - have been particularly active in this regard. According to the Organization of American States' (OAS) trade information database ${ }^{33}$, LCR countries have entered into 33 PTAs since 1994, primarily with trading partners within the Western Hemisphere, but also with the European Union and increasingly with countries in the Asia-Pacific region.

The entry into force of the NAFTA between Mexico, the US and Canada in 1994 is widely considered as a defining event in developing countries' attempts to engage in PTAs with a view to securing greater access to key markets and consolidating recent domestic reforms. Two LCR countries in particular - Mexico and Chile - have been the initial driving forces behind the proliferation of PTAs in the region over the last decade, although other countries or sub-regions (e.g. Central America) have also recently joined the fray - see Table 3 below for a chronological list of all recent PTAs in LCR. PTAs concluded in the last decade have introduced important new features such as the treatment of intellectual property rights as well as trade and investment in services (including financial services), reflecting their rising importance in economic development and world trade. However, the co-existence and proliferation of different PTA types has led to concerns about an emerging "spaghetti bowl" that creates administrative complexity among trading partners due to different and overlapping commitments and

\footnotetext{
${ }^{32}$ See Crawford J. and Fiorentino R. (2005), the World Bank (2005), and Roy M., Marchetti J. and Hoe Lim A. (September 2006) for a description of recent trends and potential drivers.

${ }^{33}$ See http://www.sice.oas.org/tradee.asp
} 
rules of origin. Such a proliferation carries the additional risk of potentially hampering the development of the multilateral trading system ${ }^{34}$.

The proliferation of PTAs in recent years can be explained by political, strategic and economic reasons that may differ depending on the level of development of participating countries. In general, these agreements are considered relatively easier and faster to negotiate, particularly in markets where geographic or cultural proximity matters, and they may allow for progress in areas where multilateral reforms are less advanced ${ }^{35}$.

“North-South” PTAs, i.e. trade agreements (typically FTAs) between developing and developed countries, had traditionally been based on unilateral preferential treatment granted to the weakest trading partner(s), but have steadily given way to agreements that grant advantages on a reciprocal basis. Economic benefits may arise from complementary resource endowments, knowledge spillovers and foreign direct investment (FDI) attraction. Apart from these benefits, political motivations for developed countries may include security issues and the creation of incentives to arrest or reverse the flow of illegal (unskilled) migration by raising standards of living in the lower income partner. In addition, developed countries may view PTAs as a tool to expand and experiment - as well as set a precedent - with new trade agenda items beyond what is currently feasible at the multilateral level (e.g. labor rights, environmental standards, investment, and competition policy). By contrast, for most developing countries, seeking entry in a PTA with a larger and richer trading partner is mainly linked to securing more predictable and greater access to key export markets (i.e. as an insurance instrument against possible future policy reversals) and attracting FDI. A related objective is the possibility for PTAs to help consolidate domestic regulatory reforms through credible external obligations. The positive "signaling" properties of trade commitments (which include the WTO) are typically used with a view to enhancing host countries’ investment climate.

"South-South" PTAs, i.e. trade agreements between developing countries, have long aimed at supporting national development strategies (e.g. infant industries) and broader political objectives, such as fostering better regional ties and increasing bargaining power in trade negotiations vis-à-vis third countries. Such agreements are today viewed as development tools to enhance competition domestically and better integrate participants into regional or global production networks and supply chains. In contrast to North-South agreements, South-South PTAs also often include arrangements designed to achieve a higher level of economic (and potentially political) integration at a sub-regional level via the establishment of customs unions and common markets. The four main South-South PTAs in LCR are the Southern Cone Common Market (MERCOSUR, established in 1991), the Andean Community (CAN, established in 1969), the Caribbean Community and Common Market (CARICOM, established in 1973) and the Central America Common Market (CACM, originally established in 1960 and reinstated in 1991) ${ }^{36}$.

\footnotetext{
${ }^{34}$ See Bhagwati J. and Panagariya A. (1997). The World Bank (2005) also reports that the average LCR country belongs to eight different PTAs, which is the highest number among developing countries.

${ }^{35}$ See Salazar-Xirinachs J.M. (October 2002) for a description of the "new regionalism" in LCR.

${ }^{36}$ A separate project to establish the Free Trade Area of the Americas (FTAA), a hemisphere-wide free trade zone, has stalled in recent years.
} 
Table 3: Coverage and Treatment of Financial Services in LCR PTAs (as of mid-2006)

\begin{tabular}{|c|c|c|c|c|}
\hline Trade Partners & $\begin{array}{c}\text { Date of } \\
\text { Signature }\end{array}$ & $\begin{array}{l}\text { Date of Entry into } \\
\text { Force }\end{array}$ & Coverage of Financial Services (FS) & FS Model \\
\hline \multicolumn{5}{|c|}{ FREE TRADE AGREEMENTS } \\
\hline $\begin{array}{l}\text { NAFTA (US- } \\
\text { Canada-Mexico) }\end{array}$ & August 1992 & 1 January 1994 & Specific FS chapter & NAFTA \\
\hline Mexico-Costa Rica & April 5, 1994 & January 1, 1995 & $\begin{array}{c}\text { No specific chapter on FS } \\
\text { Excluded from the Cross-Border Trade in } \\
\text { Services chapter }\end{array}$ & \\
\hline $\begin{array}{l}\text { Group of Three } \\
\text { (Mexico- Colombia- } \\
\text { Venezuela*) }\end{array}$ & June 13, 1994 & January 1, 1995 & Specific FS chapter & NAFTA \\
\hline Mexico-Bolivia & $\begin{array}{l}\text { September 10, } \\
1994\end{array}$ & January 1, 1995 & Specific FS chapter & NAFTA \\
\hline Chile-Canada & December 6, 1996 & July 5, 1997 & $\begin{array}{c}\text { No specific chapter on FS } \\
\text { Excluded from the Cross-Border Trade in } \\
\text { Services chapter; } \\
\text { Covered in the Investment chapter }\end{array}$ & \\
\hline Mexico-Nicaragua & $\begin{array}{l}\text { December 18, } \\
1997\end{array}$ & July 1,1998 & Specific FS chapter & NAFTA \\
\hline $\begin{array}{l}\text { Central America- } \\
\text { Dominican Republic }\end{array}$ & April 16, 1998 & $\begin{array}{l}\text { Costa Rica-DR: March 7, } \\
\text { 2002; El Salvador-DR: } \\
\text { October 4, 2001; } \\
\text { Guatemala-DR: October 3, } \\
\text { 2001; Honduras-DR: } \\
\text { December 19, } 2001\end{array}$ & $\begin{array}{c}\text { No specific chapter on FS } \\
\text { Covered under the chapters on Investments and } \\
\text { Trade in Services }\end{array}$ & NAFTA \\
\hline $\begin{array}{c}\text { CARICOM }^{37} \text { - } \\
\text { Dominican Republic }\end{array}$ & August 22, 1998 & Not yet implemented & $\begin{array}{c}\text { No specific chapter on FS } \\
\text { Covered under the Trade on Services Annex }\end{array}$ & NAFTA \\
\hline Mexico-Chile & October 1, 1998 & August 1, 1999 & $\begin{array}{c}\text { No specific chapter on FS } \\
\text { Excluded from the Cross-Border Trade in } \\
\text { Services Chapter } \\
\text { Covered under the Investment Chapter }\end{array}$ & \\
\hline $\begin{array}{l}\text { Central America- } \\
\text { Chile }\end{array}$ & October 18, 1999 & $\begin{array}{l}\text { Costa Rica: February 15, } \\
\text { 2002, El Salvador: June 3, } \\
2002\end{array}$ & $\begin{array}{c}\text { No specific chapter on FS } \\
\text { Excluded from the Cross-Border Trade in } \\
\text { Services chapter }\end{array}$ & \\
\hline Mexico-Israel & April 10, 2000 & July 1, 2000 & Services not covered by the FTA & \\
\hline $\begin{array}{l}\text { Mexico-Northern } \\
\text { Triangle } \\
\text { (El Salvador- } \\
\text { Honduras- } \\
\text { Guatemala) }\end{array}$ & June 20, 2000 & $\begin{array}{l}\text { El Salvador and Guatemala: } \\
\text { March 15, 2001; Honduras: } \\
\text { June 1, 2001; Mexico: } \\
\text { March 14, } 2001\end{array}$ & Specific FS chapter & NAFTA \\
\hline $\begin{array}{l}\text { Mexico-European } \\
\text { Community }\end{array}$ & October 2000 & March 2001 & Specific FS chapter & $\begin{array}{c}\text { GATS (+ } \\
\text { Understanding and } \\
\text { NAFTA) }\end{array}$ \\
\hline $\begin{array}{c}\text { Mexico-EFTA }^{38} \\
\text { (European Free Trade } \\
\text { Association) }\end{array}$ & November 2000 & $\begin{array}{l}\text { Mexico, Norway and } \\
\text { Switzerland: July 1, 2001; } \\
\text { Iceland: October 1, 2001 }\end{array}$ & Specific FS section & $\begin{array}{c}\text { GATS (+ } \\
\text { Understanding and } \\
\text { NAFTA) }\end{array}$ \\
\hline Canada-Costa Rica & April 23, 2001 & November 12002 & $\begin{array}{l}\text { FS excluded, but obligation to develop provision } \\
\text { for trade in services and investment in the future }\end{array}$ & \\
\hline Panama-El Salvador & March 2002 & April 2003 & Specific FS chapter & NAFTA \\
\hline Chile-EU & November 2002 & February 2003 & Specific FS chapter & $\begin{array}{c}\text { GATS (+ } \\
\text { Understanding) }\end{array}$ \\
\hline Chile-Rep. of Korea & February 15, 2003 & April 1, 2004 & $\begin{array}{c}\text { No specific chapter on FS } \\
\text { Excluded from the Cross-Border Trade in } \\
\text { Services chapter; } \\
\text { Covered under the Investment chapter }\end{array}$ & \\
\hline Chile-US & June 6, 2003 & January 1, 2004 & Specific FS chapter & $\begin{array}{c}\text { NAFTA (+ } \\
\text { Understanding and } \\
\text { FSA) }\end{array}$ \\
\hline
\end{tabular}

${ }^{37}$ CARICOM Member countries are Antigua and Barbuda, Bahamas, Barbados, Belize, Dominica, Grenada, Guyana, Haiti, Jamaica, Montserrat, St. Lucia, St. Kitts and Nevis, St. Lucia, St. Vincent and the Grenadines, Suriname, and Trinidad and Tobago.

${ }^{38}$ EFTA Member countries are Iceland, Norway, Switzerland and Lichtenstein. 


\begin{tabular}{|c|c|c|c|c|}
\hline Chile-EFTA & June 26, 2003 & December 1, 2004 & $\begin{array}{c}\text { Not covered by the chapters on Investments and } \\
\text { Services }\end{array}$ & \\
\hline $\begin{array}{l}\text { Panama-Taiwan } \\
\text { (China) }\end{array}$ & August 21, 2003 & January 1, 2004 & Specific FS chapter & NAFTA \\
\hline Mexico-Uruguay & November 2003 & July 15, 2004 & $\begin{array}{c}\text { No specific chapter on FS } \\
\text { Excluded from the Cross-Border Trade in } \\
\text { Services chapter; Covered under the chapter on } \\
\text { Investments }\end{array}$ & \\
\hline $\begin{array}{l}\text { CARICOM-Costa } \\
\text { Rica } \\
\end{array}$ & March 9, 2004 & $\begin{array}{c}\text { Barbados, Suriname, } \\
\text { Trinidad and Tobago: } 2006\end{array}$ & Services not covered by the FTA & \\
\hline $\begin{array}{c}\text { DR-CAFTA } \\
\text { (US-Costa Rica- El } \\
\text { Salvador-Guatemala- } \\
\text { Nicaragua- } \\
\text { Dominican Republic) } \\
\end{array}$ & August 5, 2004 & $\begin{array}{l}\text { El Salvador: December } \\
\text { 2004; Honduras and } \\
\text { Guatemala: March 2005; } \\
\text { Nicaragua: October 2005; } \\
\text { US: July } 2005 \\
\end{array}$ & Specific FS chapter & $\begin{array}{l}\text { NAFTA }(+ \\
\text { Understanding and } \\
\text { FSA) }\end{array}$ \\
\hline Mexico-Japan & $\begin{array}{l}\text { September 17, } \\
2004\end{array}$ & April 1, 2005 & Incorporates GATS Annex on FS & GATS \\
\hline $\begin{array}{l}\text { Chile-New Zealand- } \\
\text { Singapore-Brunei }\end{array}$ & 2005 & Not yet implemented & $\begin{array}{c}\text { Obligation to negotiate a FS chapter } 2 \text { years after } \\
\text { entry into force of the agreement }\end{array}$ & \\
\hline $\begin{array}{l}\text { Guatemala-Taiwan } \\
\text { (China) }\end{array}$ & $\begin{array}{l}\text { September 22, } \\
2005\end{array}$ & July 1, 2006 & $\begin{array}{l}\text { No specific chapter on FS; excluded from the } \\
\text { Cross-Border Trade in Services and Investment } \\
\text { chapters }\end{array}$ & \\
\hline Chile-Panama & 2006 & Not yet implemented & $\begin{array}{c}\text { FS may be incorporated } 2 \text { years after entry into } \\
\text { force of the agreement }\end{array}$ & \\
\hline Chile-China & 2006 & Not yet implemented & Services not covered by the agreement & \\
\hline Panama-Singapore & 2006 & Not yet implemented & Specific FS chapter & NAFTA \\
\hline Nicaragua-Taiwan & 2006 & Not yet implemented & N/A & \\
\hline Peru-USA & April 2006 & Not yet implemented & Specific FS chapter & $\begin{array}{c}\text { NAFTA (+ } \\
\text { Understanding and } \\
\text { FSA) }\end{array}$ \\
\hline Chile-Peru & August 22, 2006 & Not yet implemented & $\begin{array}{l}\text { No specific chapter on FS; excluded from the } \\
\text { Cross-Border Trade in Services and Investment } \\
\text { chapters; obligation to negotiate a FS chapter } 1 \\
\text { year after entry into force of the agreement }\end{array}$ & \\
\hline Colombia-USA & Not yet signed & Not yet implemented & Specific FS chapter & $\begin{array}{c}\text { NAFTA }(+ \\
\text { Understanding and } \\
\text { FSA) }\end{array}$ \\
\hline \multicolumn{5}{|c|}{ CUSTOMS UNIONS AND COMMON MARKETS } \\
\hline $\begin{array}{l}\text { MERCOSUR's } \\
\text { Protocol of } \\
\text { Montevideo } \\
\text { (Argentina, Brazil, } \\
\text { Paraguay, Uruguay, } \\
\text { Venezuela*) } \\
\end{array}$ & $\begin{array}{l}\text { December 17, } \\
1997\end{array}$ & 7 December 2005 & $\begin{array}{c}\text { Protocol of Montevideo covers services generally } \\
\text { (Annex on FS includes only specific } \\
\text { commitments) }\end{array}$ & GATS \\
\hline $\begin{array}{c}\text { CAN's } \\
\text { Decision } 439 \\
\text { (Bolivia Colombia, } \\
\text { Peru, Ecuador, } \\
\text { Venezuela*) } \\
\end{array}$ & December 1997 & Not yet implemented & Decision 439 covers services generally & NAFTA \\
\hline $\begin{array}{l}\text { CARICOM's } \\
\text { Protocol II }\end{array}$ & July 1998 & Not yet implemented & $\begin{array}{c}\text { Protocol II covers services generally; drafting of } \\
\text { a specific FS chapter in progress }\end{array}$ & \\
\hline $\begin{array}{c}\text { CACM's } \\
\text { Treaty on Investment } \\
\text { and Trade in Services } \\
\text { (El Salvador, } \\
\text { Guatemala, } \\
\text { Honduras, } \\
\text { Nicaragua) } \\
\end{array}$ & March 2002 & Not yet implemented & $\begin{array}{c}\text { Specific FS chapter in Treaty on Investment and } \\
\text { Trade in Services }\end{array}$ & NAFTA \\
\hline
\end{tabular}

Source: Own analysis, OAS SICE database.

Note: The Table only includes Customs Unions/Common Markets and post-NAFTA FTAs up to mid-2006; non-reciprocal and partial scope agreements are excluded. The dates of signature and implementation for Customs Unions/Common Markets refer to the financial services-related aspects of the relevant protocols. The Central America-Panama FTA (2002) has not been included since only the normative part of the trade agreement has been concluded to date. N/A means that the trade agreement is not currently available. * Venezuela notified its intention to withdraw from the Andean Community and the G3 FTA and, as of July 4, 2006, has acceded to MERCOSUR. 


\section{Treatment of Financial Services}

\section{Coverage in PTAs}

Compared to most other service sectors subject to the trade disciplines of PTAs, financial services are typically governed by provisions included in a separate, selfcontained chapter. Strictly speaking, however, this chapter does not always fully capture all domestic financial system activities, such as:

- foreign investment in domestic non-financial securities

- activities of non-regulated financial institutions (only NAFTA-type agreements)

- provisions on payments and capital movements

- elements of a country's 'financial infrastructure' (e.g. accounting services) and of financial institutions' functions (e.g. data processing, telecoms, legal and taxation services).

However, for analytical purposes, the paper assumes that the financial services chapter is the principal vehicle for influencing the operations of the domestic financial system.

The coverage of financial services by PTAs in LCR has tended to follow 3 main approaches (see Table 3 for a detailed description):

- no coverage because of the specific exclusion of services in general, or of financial services in particular, from the scope of a particular trade agreement (e.g. CARICOM-Costa Rica FTA, Chile-EFTA FTA $)^{39}$

- direct coverage via the introduction in the agreement of dedicated provisions in a separate chapter or annex dealing exclusively with financial services, which modifies or complements core general provisions in order to account for the special characteristics of the financial services sector (e.g. NAFTA $)^{40}$

- indirect coverage via provisions of a more generic character covering services and/or investments generally that partly apply to financial services as well (e.g. Mexico-Uruguay FTA, Chile-Rep. of Korea FTA).

PTAs that do not feature a specific chapter on financial services can nonetheless contain rules and disciplines that are indirectly applicable. First, financial services can be covered by sector-specific disciplines of a very general nature within an FTA's chapters on services and/or investment. Second, in some FTAs (e.g. Dominican RepublicCARICOM FTA, Central America-Dominican Republic FTA) as well as in MERCOSUR, the disciplines developed for services generally apply to financial services without any degree of sectoral specificity. Reference to financial services is only found in language exempting the application of general principles for purposes of regulatory carve-outs for prudential measures, balance of payments or exchange control reasons etc.

\footnotetext{
${ }^{39}$ Some of these FTAs include an obligation to negotiate a financial services chapter some time after the entry into force of the agreement.

${ }^{40}$ A variant of this approach can be found in the Mexico-Japan FTA, which deals with financial services by incorporating the GATS Annex on Financial Services. By doing so, parties to the agreement do not undertake any additional commitments on financial services among themselves from what they have already committed at the multilateral level, and do not make available the dispute settlement mechanism of the FTA to disputes related to GATS commitments between the parties.
} 
Figure 2: ‘Map’ of Financial Services-Related Trade Commitments in LCR (mid-2006)

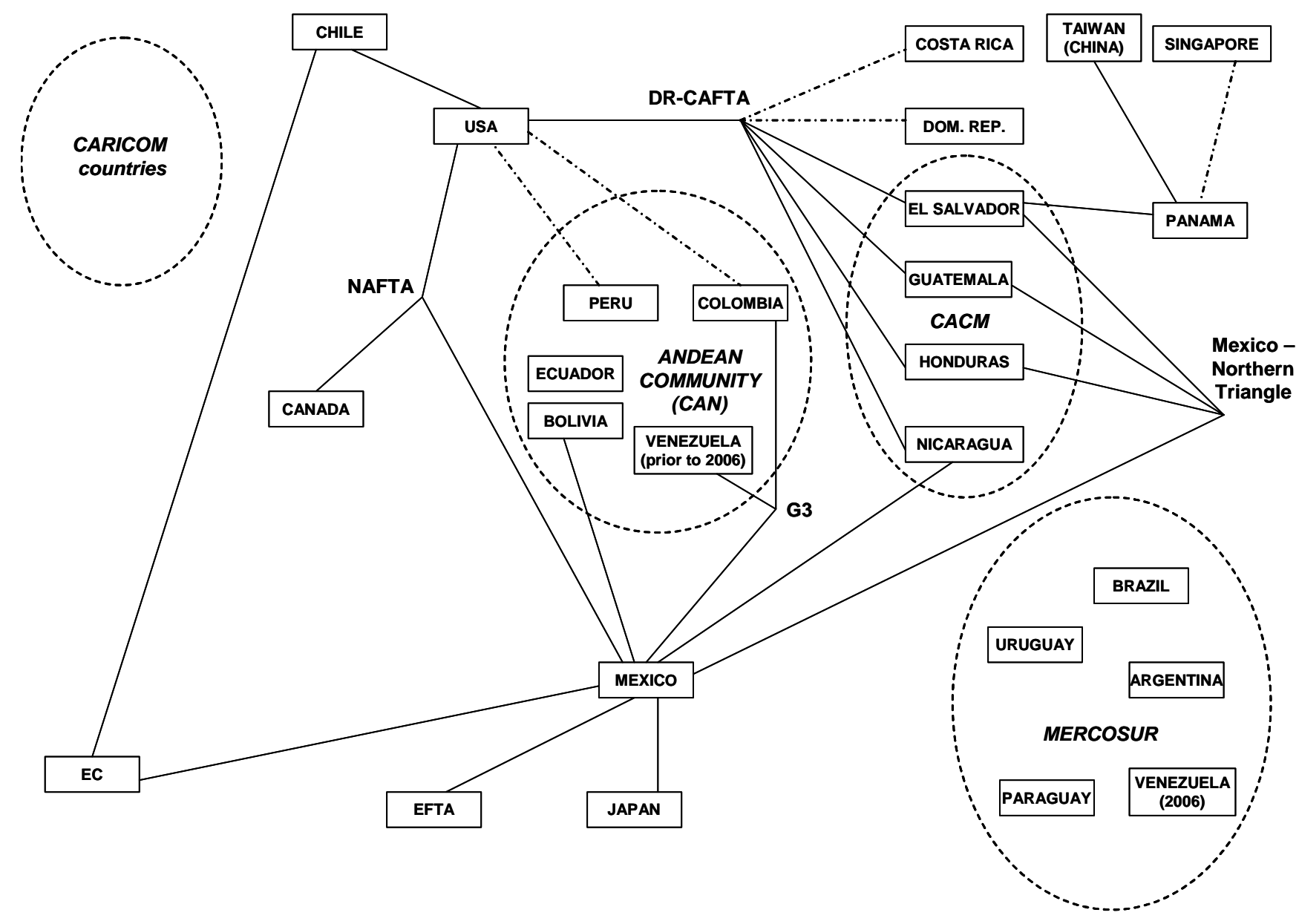

Source: Own analysis, SICE database.

Note: Lines indicate the existence of a financial services chapter/Annex in a PTA between the relevant countries (dashed lines indicate that the agreement has not yet been ratified or implemented), while the ovals indicate the presence of a trade agreement for the creation of a common market or customs union. 
The proliferation of PTAs in LCR, as well as their explicit coverage of financial services in recent years, is leading to the emergence of an increasingly complicated 'commitments map' of financial services (see Figure 2) akin to the aforementioned regional "spaghetti bowl” of PTAs. However, as Roy M., Marchetti J. and Hoe Lim A. (September 2006) note, concerns about complexity in services agreements do not relate as much to rules of origin as to the differing market access granted under various PTAs.

In general, the use of one type of coverage over another can be seen as relating to the importance given to financial services by participating countries. As can be seen in Table 3, North-South FTAs primarily tend to cover financial services directly - in fact, virtually all trade agreements involving the US and the EU have developed financial services chapters. This is a strong indication of the importance of 'offensive' interests by a trading partner's financial services industry ${ }^{41}$ that, coupled with potentially strong (and asymmetric) bargaining power, can force these services to be explicitly and comprehensively covered in a FTA. This is also confirmed by the fact that - with the exception of Central American countries ${ }^{42}$ - most foreign bank assets in LCR countries belong to banks that are headquartered in a developed country (typically the US, Canada or Europe), as can be seen in Figure 4 below $^{43}$; a similar picture would emerge if this exercise was undertaken for foreign insurance companies.

The NAFTA was the first FTA by a LCR country that included trade in financial services within its scope and devoted a specific self-contained chapter to such trade. Subsequently, Mexico has been a key player in incorporating financial services in its preferential trade agreements; of the twelve PTAs (all are FTAs) entered into by Mexico, seven contain a financial services chapter. However, it is worth noting that the majority of these agreements date back to the immediate post-NAFTA period, i.e. before Mexico's domestic financial services industry - which was significantly weakened by the 1995 tequila crisis - was (to a large extent) acquired by foreign investors.

Panama, which is an offshore financial center, is the only other LCR country that has included a financial services chapter in its South-South agreements. This is not surprising: as can be seen from Figure 3 below, most LCR countries are net importers of financial services (at least in mode 1$)^{44}$, have few - if any - perceived 'offensive' interests linked to a "demandeur" or domestic constituency, and there is therefore limited scope for - or interest in - reciprocal exchanges of concessions in the sector.

\footnotetext{
${ }^{41}$ Establishing a framework of principles for financial services trade and achieving national treatment and greater market access for US financial institutions in key markets has been a goal of US trade policy since the early 1990s - see Wagner C. (Winter 1999). This is corroborated by data from the Bureau of Economic Analysis (http://www.bea.gov/bea/di/1001serv/intlserv.htm) showing that the US has a trade surplus with Latin American countries in insurance and other financial services.

${ }^{42}$ This 'contrarian' trend in Central America is likely to change going forward as a result of the recent purchase of some of the main regional banking groups by HSBC and Citigroup.

${ }^{43}$ Although not shown in this paper, an exercise using indices of revealed comparative advantage á-laBalassa yielded similar results for most LCR countries.

${ }^{44}$ As previously mentioned, balance of payments data is insufficient to adequately capture the size and direction of financial services trade, particularly for mode 3. A crude measure for the latter can be derived from net financial services FDI or the market share of foreign players in different financial sub-sectors.
} 
Figure 3: Financial Services Trade Balance for Selected LCR Countries (1997-2004)

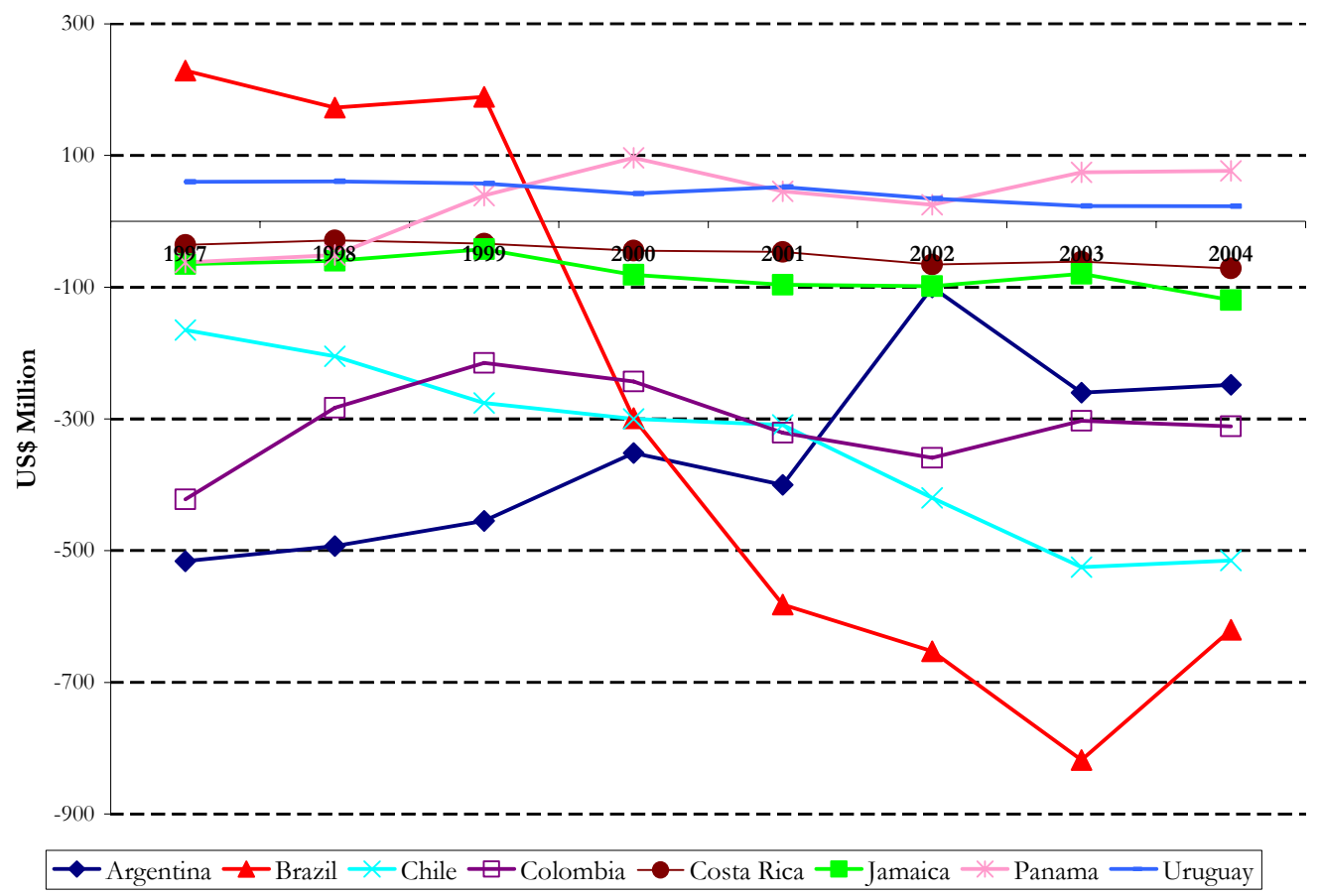

Source: Own analysis based on the IMF's Balance of Payments Statistics (2005).

\section{Figure 4: Foreign Bank Penetration in Selected LCR Countries}

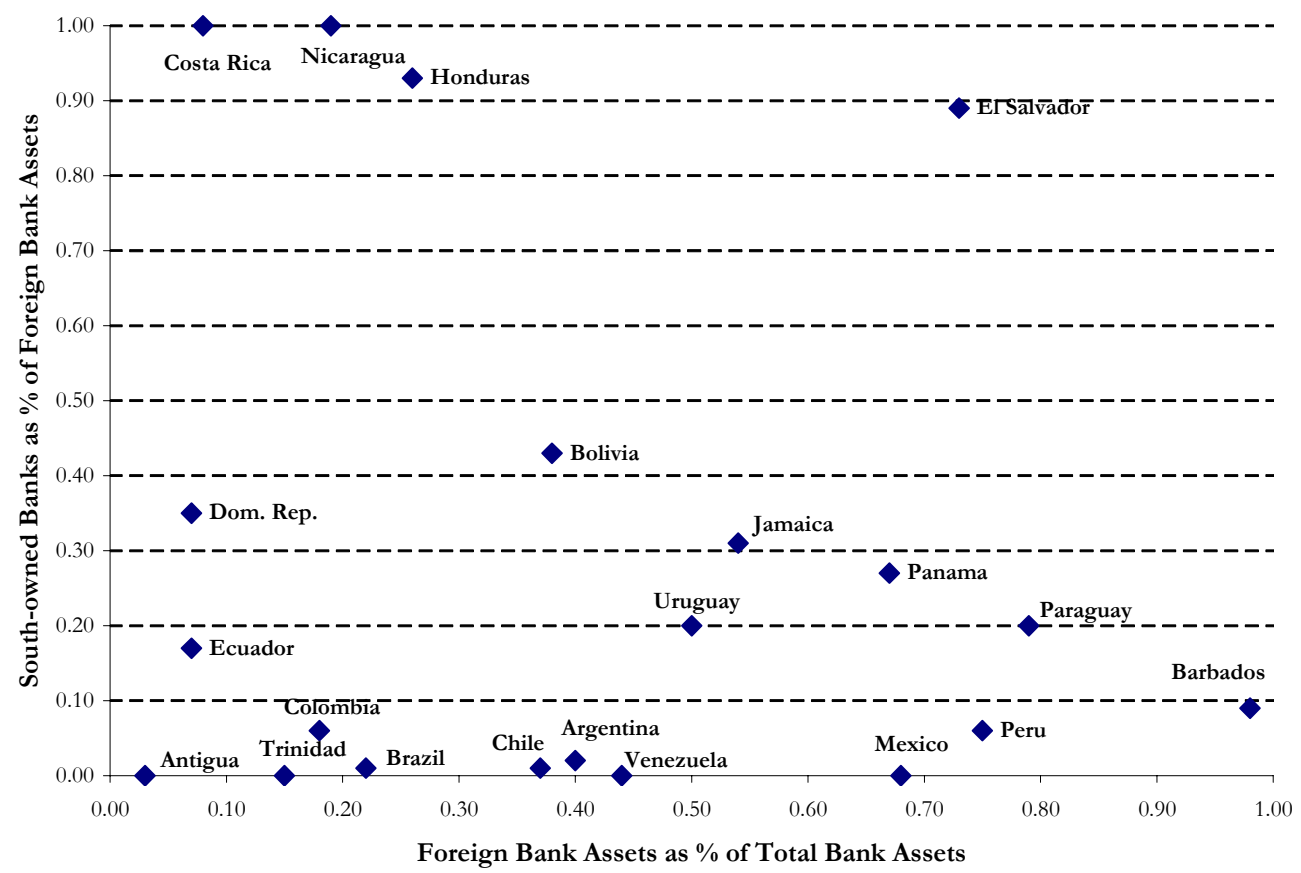

Source: Own analysis based on Van Horen N. (May 2006).

Note: A foreign bank is defined to have at least 50 percent foreign ownership. Figures reported represent averages over 2000-2004 in each country. South-owned banks are foreign banks headquartered in a developing country. 
Liberalizing trade in services (including financial services) has also been of concern within sub-regional trading blocks, but progress has been timid. CACM is the only block that has developed specific rules and disciplines for financial services via a financial services chapter in its 2002 Treaty on Investment and Trade in Services, although it has to-date only concluded the normative part of the text. Members of the CAN adopted Decision 439 ("General Framework of Principles and Rules for the Liberalization of Trade in Services") in 1997, which states the objective of achieving a market with "freely circulating services" and sets forth the modalities to be followed in pursuing liberalization. The original 2005 deadline for attaining sub-regional services trade liberalization was postponed such that the current deadline is September 2007, albeit without Venezuela. CARICOM adopted Protocol II on "Establishment, Services, and Capital Movement" in 1998 with the objective of achieving the complete elimination of restrictions to the movement of goods, services, people and capital within the sub-region; the Caribbean Single Market and Economy (CSME) initiative is supportive of these objectives. Both CARICOM and CAN members are currently developing specific text on market opening in financial services.

MERCOSUR member countries adopted the Protocol of Montevideo on Trade in Services in 1997, with the objective of achieving full liberalization of trade in services and an open regional market for services through periodic rounds of negotiations. Six such rounds have already taken place ${ }^{45}$. Uruguay, Argentina and Brazil have so far ratified the Protocol, which entered into force in December 2005. However, the lists of binding specific commitments for all three countries are relatively limited since they date back to the late 1990s, either as commitments included at the time of the Protocol's adoption (Argentina and Uruguay) or in the first round of negotiations (Brazil).

\section{Competing Liberalization Models (NAFTA versus GATS)}

PTAs that have developed disciplines on services in general (including financial services) have traditionally followed two 'architectural' models: one based on the GATS and the other based on the NAFTA. As previously mentioned, the liberalization of financial services under the GATS is based on a hybrid list approach. By contrast, NAFTA-type PTAs use a negative-list or top-down approach in which trade (crossborder and investment) in financial services is assumed to be free from discriminatory treatment except for those non-conforming measures that are explicitly included in annexes containing reservations. This approach obliges countries to list all nonconforming measures prior to an agreement's entry into force (or subject to mutually agreed longer timeframes in some instances), otherwise they are deemed to be fully and automatically liberalized (a so-called "list it or lose it" approach).

The choice of modality used to negotiate and schedule liberalization commitments can be an important contributor to the actual level and quality of liberalization attained. Although both the negative and hybrid list approaches can achieve the same level of liberalization, the former is considered in theory to be more conducive to liberalization as

\footnotetext{
${ }^{45}$ See Gary G. (summer 2004) for more details.
} 
it introduces a strong element of regulatory transparency and a potentially higher level of commitments to the extent that it typically locks in the regulatory status quo, except in those sectors where Members are explicitly allowed to retain the power to introduce new non-conforming measures. The detailed inventories of non-conforming measures that are appended to PTAs following a negative list approach, while technically more onerous to prepare, allow foreign investors and trade negotiators alike to obtain a comprehensive picture of a country's regulatory landscape ${ }^{46}$. By contrast, only the measures that apply to the sectors, sub-sectors and modes of supply entered in a country's schedule are listed under the hybrid approach, which often differ from the regulatory status quo prevailing at the time that the commitment is scheduled (so-called "status-quo minus" commitments).

While neither of the two approaches above inhibits the ability of host countries to preserve "policy space", the hybrid approach has the advantage of affording greater latitude in determining the overall level of commitments and related regulatory conditions which, as noted above, might differ from actual practice, allegedly making it more flexible or "development-friendly" than the negative list approach ${ }^{47}$.

In terms of scope and coverage, the approaches used under NAFTA- and GATS-type PTAs differ. GATS-type agreements cover the supply of financial services through the aforementioned four modes of supply, whereas NAFTA-type agreements feature separate chapters dealing with cross-border trade in services (modes 1 and 2 of GATS), investment (mode 3) and the temporary entry of business people (mode 4), the latter two being horizontal in character and applying to all subject areas covered by the PTA.

An important distinction in NAFTA-type agreements is that between regulated financial institutions that are covered by the financial services chapter, and financial services providers (which might include non-regulated financial institutions) that are subject to the investment chapter of such agreements. This implies different standards of treatment and protection for financial services providers in different countries depending on whether the country regulates their activities or not, a potentially important consideration for certain lending activities that can take place outside a bank (e.g. factoring, leasing, consumer financing). Such a distinction, and the risk of differentiated rule-making, does not arise under GATS-type agreements.

As can be seen from Table 3, the vast majority of PTAs with financial services chapters that were negotiated by LCR countries have followed the NAFTA model. This is partly explained by the role played by Mexico in using the NAFTA template in its own subsequent PTAs. In its FTAs with the Group of Three, Bolivia, Nicaragua, and the

\footnotetext{
${ }^{46}$ This is not always the case: certain negative-list FTAs in LCR during the 1990s have not developed inventories of reservations but, given the existence of standstill clauses, commit to the actual liberalization level; the development of lists in such cases becomes primarily a matter of transparency. In addition, the superior transparency properties of negative listing and the ability of PTAs adopting such a negotiating modality to generate (at least) status quo commitments can be undermined by sweeping reservations (for example, of all sub-national measures) or by allowing PTA parties to maintain the right to introduce new non-conforming measures in some sub-sectors. See also Marconini M. (May 2006) for a refutation of the commonly-held view that the NAFTA approach to liberalization is more ambitious than the GATS.

${ }^{47}$ See Sauvé P. (forthcoming) for more details.
} 
Northern Triangle (El Salvador, Honduras and Guatemala), Mexico included financial services chapters that were almost identical to the rules and disciplines found under NAFTA. These agreements all opt for the negative list approach to scheduling commitments in financial services, with lists of reservations included in separate Annexes. Because of the experience acquired in negotiating this type of FTA and the influence of the US, other LCR countries have developed templates similar to NAFTA in their own FTAs. Panama, for instance, used the NAFTA template in negotiating its FTAs with Taiwan, Singapore and El Salvador.

Illustrating the iterative, learning-by-doing, interaction between regional and multilateral negotiations in services, recent agreements between the EU and Mexico and the EU and Chile, as well as agreements negotiated recently by the US, have introduced some innovations to the traditional NAFTA and GATS templates ${ }^{48}$. FTAs concluded by the EU with Mexico and Chile mix in elements of the GATS (i.e. positive-list approach), NAFTA (i.e. provisions on the right of establishment and cross-border trade, standstill obligation for the EU-Mexico FTA), and of the GATS Understanding on Commitments in Financial Services (i.e. provisions on new financial services and on data processing). In the case of FTAs negotiated with the US, the relevant NAFTA chapter template still serves as the basis for the treatment of financial services, but provisions from the GATS were also incorporated ${ }^{49}$.

In the case of MERCOSUR, the Montevideo Protocol is modeled after the GATS in following a positive list approach with respect to national treatment and market access, and Members undertake specific commitments in national schedules that are found in the Protocol's Annex on Financial Services. New national schedules of commitments in services, including financial services, were adopted in July 2006 by Members but have not yet entered into force. In addition, MERCOSUR Members agreed in 2001 to a transparency exercise consisting of the listing of all existing restrictions in services trade with a view to their progressive removal ${ }^{50}$; this transparency exercise is complemented by a "status quo" provision prohibiting the adoption of new restrictions. However, little progress has been achieved to-date in listing these restrictions.

In the Andean Community, Decision 439 adopts the NAFTA's negative list approach. The Andean liberalization process is also based on the adoption of country inventories of non-conforming measures with regard to the market access, MFN and national treatment principles (Article 14 of Decision 439). Once inventories are adopted, Decision 439 requires CAN Members to progressively eliminate listed measures through annual negotiations coordinated by the General Secretariat. The Andean Community Commission adopted Decision 510 (“Adoption of the Inventory of Measures Restricting

\footnotetext{
${ }^{48}$ See Contreras P. (2005) for more details.

${ }^{49}$ Examples include the adoption of a positive-list approach for the cross-border supply of financial services, the treatment of potentially sensitive information, as well as the introduction of a binding - as opposed to "best endeavors" as in NAFTA - market access provision listing the types of restrictive measures that Parties cannot adopt or maintain with regard to investors or providers of another Party. ${ }^{50}$ See Stephenson S. (2002) for more details.
} 
Trade in Services”) on October 31, 2001, and the lists of member countries were made publicly available.

Protocol II of CARICOM does not establish a specific approach to services liberalization, but it mandates the elaboration and exchange of national inventories of measures affecting trade in services. Listed restrictions pertaining to measures impeding the provision of services, the movement of capital and the right of establishment are to be progressively eliminated through a program to be established upon entry into force of the Protocol. CARICOM Members' inventories were completed in 2002. The Protocol also contains a "status quo" or standstill provision, prohibiting Members from adopting new measures restricting the provision of services by CARICOM nationals.

Finally, with respect to the CACM, the Financial Services Chapter of the Treaty on Investment and Trade in Services is modeled on NAFTA and is very similar to that agreement's financial services chapter in terms of coverage.

\section{Financial Services-Related Rules and Disciplines}

This sub-section provides a general overview of some of the main rules and disciplines applicable to financial services in LCR PTAs, but does not enter into the specificities of each agreement (see the following section for a detailed analysis of the financial services liberalization commitments found in specific trade agreements).

The rules and disciplines contained in PTAs with regards to financial services have two main objectives: (1) to liberalize trade in financial services through the removal of discriminatory and market access-impeding measures affecting foreign financial services suppliers; (2) to promote better regulatory practices (e.g. on transparency), ${ }^{51}$ while also allowing countries to regulate their financial services markets on prudential grounds. In particular, trade liberalization under the different PTAs entered into by LCR countries is based on the non-discriminatory principles of MFN and national treatment, on granting foreign financial services suppliers the right to provide financial services through investment and cross-border trade, and on the elimination of market access barriers.

National treatment: All PTAs include a provision on national treatment requiring that parties to the agreement grant to financial services and financial services suppliers from another party treatment no less favorable than that accorded to like financial services and financial services suppliers of national origin. The national treatment provision applies to both cross-border trade and investment in financial services, and is either of general application (as in NAFTA-type agreements) or only for scheduled sectors, sub-sectors and modes of supply (as in GATS-type agreements). The obligation does not require that measures applicable to foreign and national suppliers be identical - rather, the focus is on the effective results of the treatment (i.e. de facto rather than de jure national treatment). NAFTA and NAFTA-type agreements foresee that host country measures, whether

\footnotetext{
${ }^{51}$ Marconini M. (May 2006) defines four main aspects of domestic regulation in PTAs: transparency (contact points, publications, notifications etc.), governance (tribunals, prior comments, reviews and appeals, authorization etc.), requirements and recognition.
} 
providing different or identical treatment, must offer "equal competitive opportunities" so that foreign services or service providers are not placed at a competitive disadvantage relative to domestic services and services suppliers deemed to be in like circumstances.

MFN: The MFN obligation is included in most of the PTAs entered into by LCR countries and is of general application under both NAFTA-type and GATS-type agreements. It requires that parties to the agreement grant immediately and unconditionally to financial service suppliers from another party the most favorable treatment accorded to any of their trading partners. Since national treatment and MFN are of general application in NAFTA-type agreements, the better of the two treatments needs to be granted to financial services and service suppliers from the other party. The MFN provision in most NAFTA-type agreements also guarantees that any additional advantage flowing from an agreement subsequently entered into by a Member with a third country is fully and automatically extended to all other Members.

Market access: Market access provisions refer to the conditions under which a foreign financial services supplier is allowed to enter and operate within a domestic market, and typically list a set of specific measures that parties cannot maintain or adopt without reserving them. Under GATS-type agreements, countries undertake specific market access commitments in relation to the four modes of supply. By contrast, NAFTA-type agreements traditionally often did not contain a provision on market access per se, but included a general provision on the right of establishment applicable to cross-border trade and investment, together with disciplines on non-discriminatory quantitative restrictions as well as the right to non-establishment (local presence) meant to encourage the crossborder supply of services. However, more recent agreements entered into by the US include a market access provision applicable to trade and investment in financial services along GATS lines.

In NAFTA-type agreements, the right of establishment provision grants investors of a party the right to establish a financial institution in the territory of another party. Such a right is normally supplemented with the ability for investors to choose the juridical form of establishment that best serves their needs, subject to reservations. The cross-border trade provision states that parties should allow the supply of financial services and permit persons located in their territory to purchase financial services from suppliers located in the territory of another party, but does not automatically allow such suppliers to do business, carry on commercial operations, solicit, market or advertise their activities. All measures in place that do not conform to the rules on the right of establishment and crossborder trade need to be listed in Annexes if Parties wish to maintain them after a PTA's entry into force.

NAFTA-type agreements - in common with the GATS Understanding on Commitments in Financial Services - sometimes include a "standstill" rule on existing non-conforming measures, which prohibits parties from adopting any law or regulation that would increase the level of non-conformity of its listed measures. The importance of the standstill relates to the depth of commitments undertaken by parties as it involves 'freezing' the existing regulatory regime by undertaking a commitment not to make 
measures more non-conforming in the future. The existence of a standstill provision may have motivated countries in recent PTAs to bind their commitments at the level of the regulatory status quo. In addition, these agreements typically go a step further than standstill by adding a "ratcheting" clause under which, when a Party unilaterally amends a listed non-conforming measure, it automatically locks in the new liberalization and is prohibited from 'backsliding' towards the original non-conforming measure.

New financial services: PTAs contain language requiring Parties to permit financial services suppliers to offer new financial services of a type similar to services allowed for national suppliers under domestic law. The purpose of this provision is to allow innovative products introduced by financial institutions in their countries, and approved by their home country authorities, to be introduced and sold abroad. However, host countries may, on prudential grounds, refuse to allow a particular service or a particular type of entity to provide any "new financial services" in its territory.

Transparency: All trade agreements entered into by LCR countries contain general disciplines on transparency requiring the prompt notification or publication of measures affecting trade and investment in the sector. Transparency provisions also require that the authorization application process be transparent and not unduly burdensome. In addition, more specific and detailed disciplines are also developed in financial services chapters, such as the obligation to notify other parties of measures of general application that a Party proposes to adopt (under NAFTA-type agreements); some agreements extend such a prior notification obligation to "interested persons" with an opportunity for comments (e.g. Chile-US FTA). Some financial services chapters also include the obligation to inform applicants of the decision concerning the application within a fixed period of time (for example, within 120 days in the case of NAFTA) and to provide them with information concerning the status of their application.

Recognition: Several PTAs contain provisions relating to the harmonization of standards applicable to financial activities and the setting up of arrangements designed to encourage mutual recognition of licensing and prudential standards. Indeed, NAFTAtype agreements consider the possibility for Parties to recognize prudential measures adopted by another party or by a non-Party. As in the GATS, any such mutual recognition can be extended on a preferential basis, i.e. it is an accepted derogation from MFN treatment. PTAs entered into with the EU require parties to "endeavor" to implement and apply non-binding international standards for regulation and supervision in the financial services sector and the fight against money laundering. For example, the EU-Mexico FTA indicates that Parties should implement international standards set by the Basle Committee, the IAIS, and IOSCO.

Prudential safeguards: PTAs covering financial services typically feature provisions securing the right of governments to pursue domestic regulatory and macroeconomic policies. The prudential carve-out contained in these chapters recognizes the right of countries to adopt or maintain prudential measures for: (1) the protection of investors, depositors, financial market participants, policy-holders, policy-claimants, or persons to whom a fiduciary duty is owed by a financial service supplier; (2) the maintenance of the 
safety, soundness, integrity or financial responsibility of financial service suppliers; (3) ensuring the integrity and stability of a Party's financial system. As with the GATS, prudential measures remain subject to dispute settlement under PTAs.

In terms of macroeconomic policies, another common feature of PTAs is the introduction of a provision guaranteeing the rights of countries to take actions in order to carry out non-discriminatory monetary, credit and exchange rate policies. Moreover, as under the GATS, activities or services forming part of a statutory system of social security or public retirement plan, as well as activities conducted by a public entity for the account or with the guarantee or using the financial resources of the Government (e.g. an export credit agency), are typically excluded from the scope of the financial services chapter.

Capital flows: PTAs incorporate provisions requiring governments to allow transfers of profits, interest and other payments associated with an investment. GATS-type agreements also require governments to allow capital flows when undertaking a commitment, but only to the extent that the movement of capital is an essential part of the service itself. Moreover, most agreements allow governments to impose restrictions on current or capital transactions in the event of serious balance-of-payment and external financial difficulties, or the threat thereof. In NAFTA-type agreements, parties may prevent or limit transfers through the equitable, non-discriminatory and good faith application of measures relating to the maintenance, safety, soundness, integrity or financial responsibility of financial institutions or cross-border financial service providers. However, the broad definition of investment adopted in recent agreements, which has tended to include both FDI and short-term portfolio flows, has led to some friction when negotiating provisions on the use of pre-existing measures for 'speculative' capital flows ${ }^{52}$.

Denial of benefits: Provisions on denial of benefits - also known as rules of origin allow parties to a PTA to deny the benefits of the agreement to a financial services supplier that is not owned or controlled by nationals of the other party. These provisions can be important because their restrictiveness helps determine the extent of preferential treatment entailed in market opening commitments undertaken by the parties ${ }^{53}$. While the WTO framework defines service suppliers as a legal entity under majority ownership and effective control, denial of benefits provisions in NAFTA and NAFTA-type agreements (usually 'imported' into the financial services chapter from the investment chapter) establish a double criterion of "domestic ownership or control" and "substantial business activities or operations". This strengthens the preferential nature of the commitments made by preventing the establishment of 'shell' companies in the territory of a party by suppliers from third countries to take advantage of benefits arising from the agreement.

\footnotetext{
${ }^{52}$ For example, in the case of the US-Chile FTA, the two parties agreed in an Annex that measures adopted by Chile (such as applying a restriction on payments and transfers) could be subject to dispute settlement by US investors. Different types of claims were identified in order to distinguish between short-term and longer-term capital flows, with restrictions on the latter being more penalizing for Chile.

${ }^{53}$ See Sauvé P. and Beviglia-Zampetti A. (2006), as well as Fink C. and Nikomborirak D. (forthcoming), for an analysis of rules of origin in services.
} 
Dispute settlement: All PTAs include provisions submitting disputes arising from the agreement to arbitration thereby allowing for an increased degree of legal certainty for investors. An important feature of PTAs, also found under the FSA, relates to the obligation that panelists appointed to dispute panels have the necessary expertise relevant to the specific financial service under dispute, as well as expertise in financial services law or practice. Moreover, NAFTA-type agreements tend to include both investor-tostate and state-to-state dispute settlement mechanisms in financial services ${ }^{54}$, and require that countries establish a roster of financial services experts that are willing to serve as panelists, some of whom may be non-Party nationals.

The application of trade policy disciplines in financial services can facilitate better regulatory practices (e.g. transparency) and constrain the arbitrary abuse of 'policy space' by the authorities (e.g. via standstill or ratcheting clauses). However, the latter issue remains somewhat of a paradox. On the one hand, policymakers, especially in developing countries, need to maintain policy flexibility and some regulatory discretion in order to properly balance financial stability, economic efficiency and social equity considerations that go beyond trade liberalization per se. On the other hand, they also need to provide credible assurances to foreign investors of a stable business environment by committing to increasingly liberalized (and costly to reverse) policy regimes ${ }^{55}$. It is possible that the regulatory status quo in financial services might not be the most appropriate level for countries to bind and that the right answer might depend on countries' level of financial development, but there is little research or empirical analysis on this topic ${ }^{56}$.

\footnotetext{
54 This can potentially be an important consideration as investors can launch cases themselves in investorto-state arbitration, while they would need the support of their home government for state-to-state disputes.

${ }^{55}$ As the recent example of Venezuela shows, there are also political limits to the commitment value of trade agreements.

56 This inherent contradiction is also the subject of the current round of multilateral trade negotiations; however, as Marconini M. (May 2006) notes, the emphasis on development there means that "the overriding objective is to preserve the space to make policy - development policy - and to avoid any possible further encroachment into the domestic regulatory realm".
} 


\section{Analysis of Financial Services Commitments}

\section{Comparison to GATS}

Have recent PTAs led to increased financial services liberalization commitments for relevant LCR countries when compared to those made under the GATS? This question can only be answered empirically by reviewing the market access and national treatment commitments scheduled in the financial services chapters of LCR PTAs for individual countries. This analysis has been undertaken for a sample of LCR countries that have recently participated in PTAs (Chile, Colombia and Costa Rica) and is described below, while the comparative country tables are shown in Appendix II.

Chile $^{57}$ : The majority of Chile's financial services commitments under the GATS related to mode 3 (commercial presence), although an economic needs test and limitations on juridical form of establishment were also maintained. Mode 4 (movement of natural persons) commitments were only limited to intra-company transferees relating to mode 3 operations, while only liberalization commitments for reinsurance and retrocession services were undertaken in mode 1 (cross-border trade). National treatment provisions were generally consistent with market access commitments across sub-sectors and modes of supply, although there were additional restrictions on the proportion of local staff employed within foreign financial institutions and on the ability of foreign investors to repatriate capital. A market access limitation for all supply modes was introduced in order to maintain the Central Bank's broad powers to impose exchange controls and capital restrictions, especially the unremunerated reserve requirement on short-term foreign capital inflows ("encaje”). Since no commitments related to the social security system were undertaken, mandatory defined contribution pension funds were not subject to any liberalization undertakings.

Both the US-Chile FTA (2004) and the EC-Chile Association Agreement (2003) have led to significant, "GATS+" liberalization commitments. The economic needs test for commitments in specific sub-sectors was abolished under both agreements ${ }^{58}$, while mode 3 commitments were made for the first time in regard to certain auxiliary financial services, management of voluntary pensions savings plans, provision and transfer of financial information and financial data processing. The cross-border brokerage and sale of MAT (marine, aviation and transport) insurance was also allowed. The US-Chile FTA went further by allowing the consumption abroad (mode 2) of all financial services by Chilean nationals ${ }^{59}$, by liberalizing factoring services under mode 3 and the cross-border management of collective investment schemes, and by permitting insurance branching

\footnotetext{
${ }^{57}$ See Saez R. (2006) for more details.

${ }^{58}$ As a result of the different 'architectural' models, the abolition of the economic needs test applies to establishment in all financial services (unless a reservation is made) for the US-Chile FTA, but only in those financial services where market access commitments were made for the EC-Chile FTA.

59 The liberalization of consumption abroad does not include mandatory insurance services or those related to the social security system. In addition, Chile is not required to permit cross-border suppliers to do business or solicit in its territory, while their registration may also be required.
} 
(subject to Chilean regulations) no later than 4 years after the entry into force of the agreement. Moreover, the US and Chile established dispute settlement provisions that permit the submission of claims by US investors in case Chile breaches an obligation by applying specific restrictions on payments and transfers; unlike GATS, no safeguard provisions in case of balance of payments problems were included in the agreement.

Colombia $^{60}$ : As with Chile and most WTO Members, Colombia's financial services commitments under GATS were primarily undertaken with regard to mode 3, although an economic needs test and limitations on juridical form of establishment and prior government authorization were maintained for some financial services. No mode 2 commitments were made in any financial services sub-sector, while mode 4 commitments were limited to natural persons who are managers, legal representatives or specialists. Only liberalization commitments for reinsurance and retrocession services, and for foreign trade-related direct insurance, were undertaken with regard to mode 1 . National treatment provisions were similar to market access commitments across sub-sectors and supply modes, although there were additional restrictions on the proportion of local staff employed and on the privatization of state-owned entities. Finally, Colombia took an MFN exemption that conditioned access to its domestic market (including for financial services) through commercial presence on a reciprocity basis.

The US-Colombia FTA (concluded but not yet ratified as of end-2006) includes important additional liberalization commitments in financial services. Numerical and juridical restrictions on establishment (including an economic needs test) are abolished except when existing legislation mandates a specific juridical form, while entry in insurance and banking via direct branching are to be permitted (subject to Colombian regulations) no later than 4 years after the entry into force of the agreement. Additional commitments include certain investment advice and portfolio management services for collective investment schemes (modes 1 and 3) and mandatory pension funds (mode 3), and all remaining banking and other financial services that were not already covered under mode 3 in the GATS (e.g. settlement and clearing services for financial assets). For the first time, Colombia agreed to commitments on consumption abroad of all financial services by Colombian nationals ${ }^{61}$ (no later than 4 years after the entry into force of the agreement), as well as commitments on the cross-border supply of MAT insurance sales and brokerage, services auxiliary to insurance and provision and transfer of financial information, financial data processing and certain auxiliary financial services.

Costa Rica ${ }^{62}$ : Costa Rica did not schedule any GATS commitments in insurance due to the existence of a state monopoly in the sector (Instituto Nacional de Seguros). With regards to banking and other financial services, Costa Rica liberalized the provision and transfer of financial information and financial data processing for all cross-border modes of supply, while mode 4 commitments were limited to the entry and temporary stay of

\footnotetext{
${ }^{60}$ See Arbeláez, M. A., Flórez A. and Salazar N. (August 2006) for more details.

61 This does not include mandatory insurance services or those related to the social security system or when the policy holder, insured or beneficiary is a State entity. In addition, Colombia is not required to permit cross-border suppliers to do business or solicit in its territory, while their registration may also be required.

${ }^{62}$ See Echandi R. (2006) for more details.
} 
senior executives of an enterprise. Other mode 3 commitments included basic banking and financial leasing services, although limitations on juridical form of establishment (e.g. no entry via branching) were maintained. National treatment provisions were similar to market access commitments across sub-sectors and supply modes.

The DR-CAFTA (not yet ratified by Costa Rica as of end-2006) introduces significant new liberalization commitments in financial services. The most important ones relate to insurance, where the right of establishment is gradually liberalized by 2011, with the exception of compulsory auto, occupational risk and social security-related insurance $^{63}$. The cross-border sale and intermediation of MAT insurance, reinsurance and retrocession, and of services auxiliary to insurance are also included in Costa Rica's liberalization commitments. For the first time, consumption abroad of all banking and other financial services by Costa Rican nationals ${ }^{64}$ is permitted, while advisory and other auxiliary financial services excluding intermediation are liberalized for modes 1, 2 and 4. Additional commitments include the cross-border provision of certain investment advice and portfolio management services for collective investment schemes, and all remaining banking and other financial services that were not already covered under mode 3 in the GATS (e.g. guarantees and commitments, trading for own account or for account of customers, securities participations, money broking etc.).

Figure 5 below provides a visual representation of the market access liberalization commitments undertaken by all three countries in modes 1, 2 and 3; mode 4 is excluded given its highly restrictive nature that makes it relatively unimportant for financial services, while national treatment provisions are also excluded since they are generally similar to those governing market access. Although a very crude approximation since it does not weigh different modes and sub-sectors by their relative size and does not incorporate horizontal restrictions, Figure 5 reveals that commitments are more extensive across all modes for PTAs involving the US, particularly for mode 2. In general, given that GATS obligations already cover 'core' banking services, the bulk of additional commitments for these countries were made in insurance, securities-related activities (e.g. trading, underwriting, asset management) and other financial services (e.g. transfer of financial information, data processing, advisory services etc.).

\footnotetext{
${ }^{63}$ Costa Rica also committed to establish an independent insurance regulatory authority by January 2007.

${ }^{64}$ Costa Rica is not required to permit cross-border suppliers to do business or solicit in its territory, while their registration may also be required.
} 
Figure 5: Proportion of Financial Services Sub-Sectors Committed by Chile, Colombia and Costa Rica in the GATS and in Subsequent FTAs

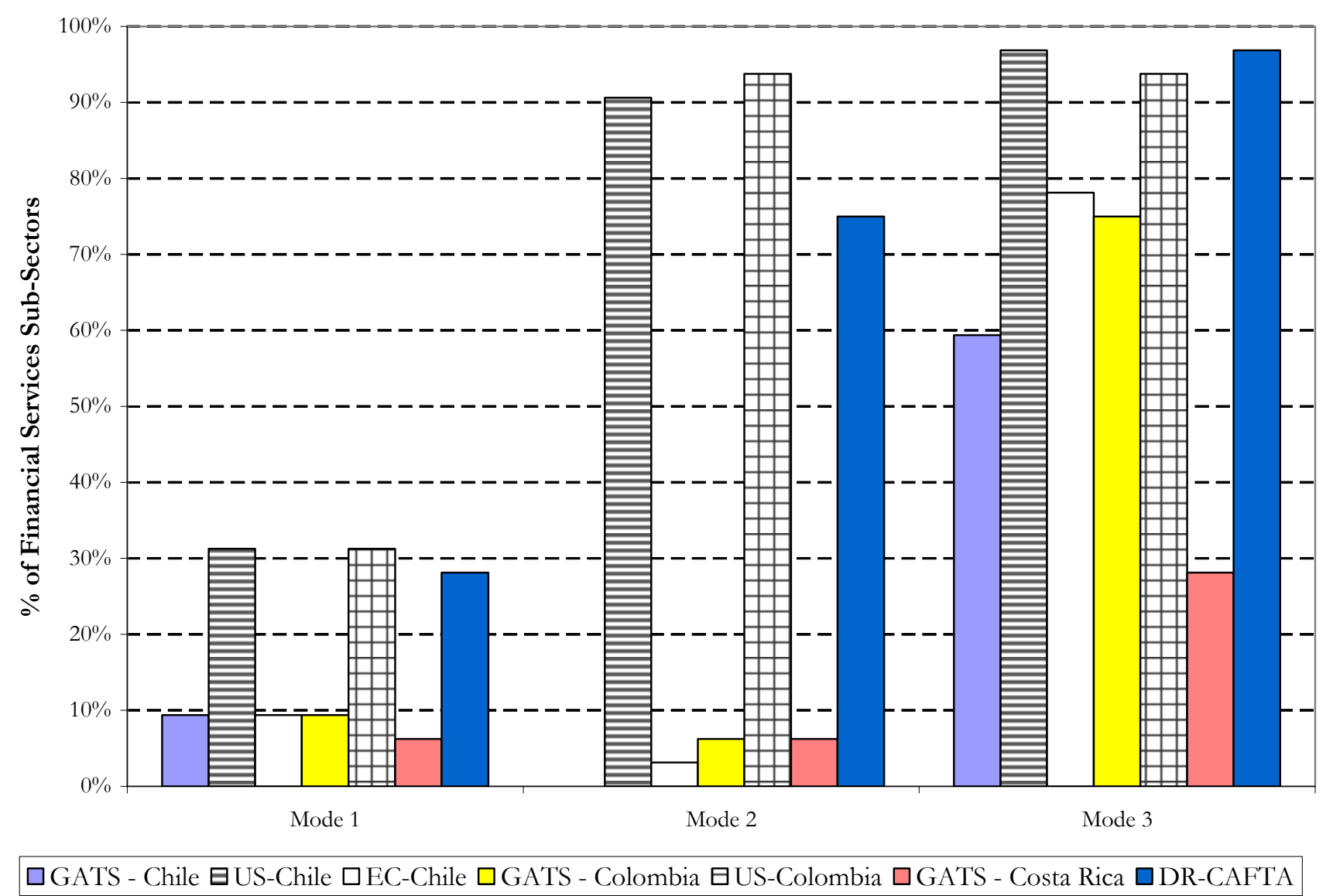

Source: Authors' interpretation based on WTO and USTR information, Contreras P. and Yi S. (December 2003), Contreras P. (2005), Saez R. (2006), Arbeláez M. A., Flórez A. and Salazar N. (August 2006) and Echandi R. (2006).

Note: Three levels of market access commitments are applied in the above analysis by financial services sub-sector and mode: none (value of zero), partial (value of 0.5) and full commitment (value of 1). Mode 4 commitments, as well as all national treatment commitments and horizontal restrictions, are excluded. All pre-commitments to liberalize additional sub-sectors and/or modes in future years are included. 


\section{Comparison to the Status Quo (Unilateral Liberalization)}

Have recent PTAs led to actual liberalization of financial services as opposed to merely binding the status quo? Once again, this question can only be answered by reviewing individual LCR country experiences, although this is much more difficult to address because of insufficient information on the regulatory status quo (both in terms of standards and actual practice) prior to, during and after the implementation of such trade agreements. A review of the existing literature for the aforementioned countries (Chile, Colombia and Costa Rica) provides some clues and may be deemed indicative (though not necessarily representative) of other LCR countries participating in PTAs.

After a long process of unilateral trade and investment liberalization, Chile's first significant financial services commitments were made in the GATS where, as Saez R. (2006) explains, "Chile followed a very conservative and cautious approach in negotiating its financial services schedule... and did not consolidate the status quo". In spite of the aforementioned additional liberalization commitments in the EU-Chile and US-Chile FTAs, there is minimal de novo liberalization. Chile's reservations mainly relate to existing provisions in its financial services legislation, the only envisaged legal change being the establishment of branching in insurance (not introduced as of end2006). However, virtually no significant commitments were made in the management of mandatory pension funds, which form part of Chile's social security system, in spite of that sector's importance in the domestic financial system (assets of around 60 percent of GDP) and its openness (see below).

Colombia's first liberalization commitments in financial services stem from the G3 agreement with Mexico and Venezuela that was implemented in 1995 and, as Arbeláez, Flórez and Salazar (2006) describe, "the commitments undertaken by Colombia (and Venezuela) in financial services did not exceed what was already covered by existing legislation". Subsequent commitments under GATS merely consolidated what was already covered in existing domestic legislation, thereby binding at or below the status quo. Colombia is also a member of the Andean Community but, as previously mentioned, services commitments have yet to be made by its Members.

In contrast to previous trade agreements, Colombia's recently-concluded FTA with the United States introduces modest liberalization in financial services when compared to the status quo. Foreign bank and insurance company branching represents a new juridical form of establishment, while new cross-border liberalization commitments (particularly for consumption abroad of insurance services by Colombian residents) are substantial. In addition, the permission to partially outsource some investment advice and portfolio management services granted to domestic collective investment schemes and mandatory pension funds is an important difference with current practice and will likely impact the structure of that market segment. As with Chile, however, virtually no significant liberalization commitments were made with respect to mandatory pension funds in spite of that sector's de facto openness (see below) ${ }^{65}$.

\footnotetext{
${ }^{65}$ In the case of Chile and Colombia, protection for (at least some) existing pension funds that are owned by foreign investors comes from the bilateral investment treaties that these countries have signed.
} 
Costa Rica's international commitments in financial services first took place in the GATS, and they consolidated unilateral liberalization reform efforts that had been recently implemented (e.g. the dismantling of the State monopoly over sight deposits). In spite of signing FTAs with several Western Hemisphere countries over the last decade, no financial services chapter was included until the advent of DR-CAFTA. In fact, as Echandi R. (2006) notes, "until the DR-CAFTA was negotiated, no international agreement entailed for Costa Rica any obligation beyond the level of liberalization already granted by the domestic legal framework applicable to financial services". Even though DR-CAFTA did not lead to further liberalization of Costa Rica's banking sector or resolve other types of non-discriminatory treatment (e.g. non-level playing field between private/foreign and state-owned banks), its insurance liberalization provisions represent an important example of a new trade commitment that goes significantly beyond the country's previous level of openness of the domestic financial system ${ }^{66}$. In that respect, the FTA appears to have been used as a means of advancing the government's (stalled) domestic reform agenda in the financial sector.

The three case studies appear to indicate that FTAs in the LCR region have in general contributed relatively modestly so far to further market opening (de novo liberalization) in financial services. In addition to Costa Rica's insurance sector, real liberalization appears to have taken place in the cross-border provision of some insurance services, as well as in asset management and auxiliary financial services. Although there is limited available data on the actual market size of these sub-sectors and modes, anecdotal evidence suggests that they are relatively less important than 'core' banking- and securities-related services. However, the abolition of numerical quotas (e.g. economic needs test) and certain juridical restrictions on forms of entry (e.g. insurance branching ${ }^{67}$ ) might also contribute to further liberalization in other sub-sectors under mode 3.

The above finding provides a strong indication that PTAs are primarily used to consolidate and 'lock in' existing unilateral liberalization efforts rather than engage in new market opening ${ }^{68}$. However, this conclusion is based on a limited sample of countries used in the analysis and more work is needed to corroborate such findings. In addition, the relatively high unilateral openness of these countries' financial systems might also be partly responsible for such a finding. As can be seen from Figure 6, with the exception of Costa Rica's insurance sector, foreign financial institutions already had sizeable market shares in most domestic financial system segments at the time of the relevant FTA negotiations. The international financial integration of these countries when judged on a de facto basis (see Figure 7$)^{69}$ - also appears relatively high in an

\footnotetext{
${ }^{66}$ Echandi R. (2006) states that all other Central American countries in DR-CAFTA also undertook commitments that entailed real liberalization (i.e. reform to their domestic legislation) such as, for example, in insurance branching and portfolio management services.

${ }^{67}$ However, it should be noted that domestic authorities retain the right to regulate such branches as they deem necessary for prudential purposes, including via the establishment of local capital requirements.

${ }^{68}$ This is also compatible with the World Bank's (2005) finding that autonomous liberalization accounts for the lion's share of trade liberalization in goods since the 1980s.

${ }^{69}$ See Kose A. M., Prasad E., Rogoff K. and Wei S. (August 2006) for a discussion of de facto versus de jure (i.e. exchange restrictions, capital controls and certain prudential measures) financial integration.
} 
international context, implying that important cross-border financial linkages already existed prior to the negotiation of PTAs.

\section{Figure 6: Market Share of Foreign Financial Institutions in the Domestic Financial Systems of Chile, Colombia and Costa Rica at the Time of FTA Negotiations}

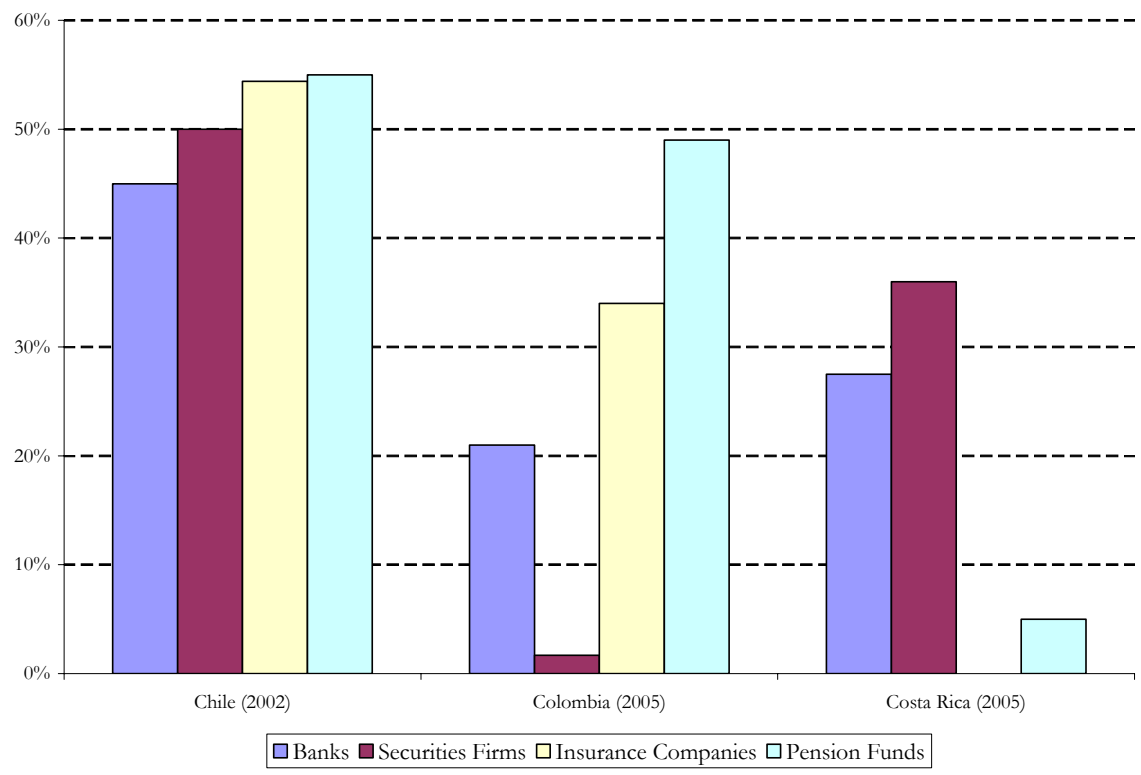

Source: Own analysis based on de la Cruz and Stephanou (2006), Echandi (2006) and Saez (2006).

Note: Percentages are based on total assets for banks (credit institutions in the case of Colombia), number of foreign firms registered in the domestic stock market (Costa Rica) and total trading volumes (Chile and Colombia) for securities firms, total premiums (Chile) and life/non-life assets (Colombia and Costa Rica) for insurance companies, and total mandatory pension assets under management for pension funds (the Costa Rica figure is an estimate). The foreign market share in the securities sector is likely underestimated since many securities activities - such as trading - are actually provided (offshore and on-shore) by banks.

\section{Figure 7: International Financial Integration of Chile, Colombia and Costa Rica} (1997-2004)

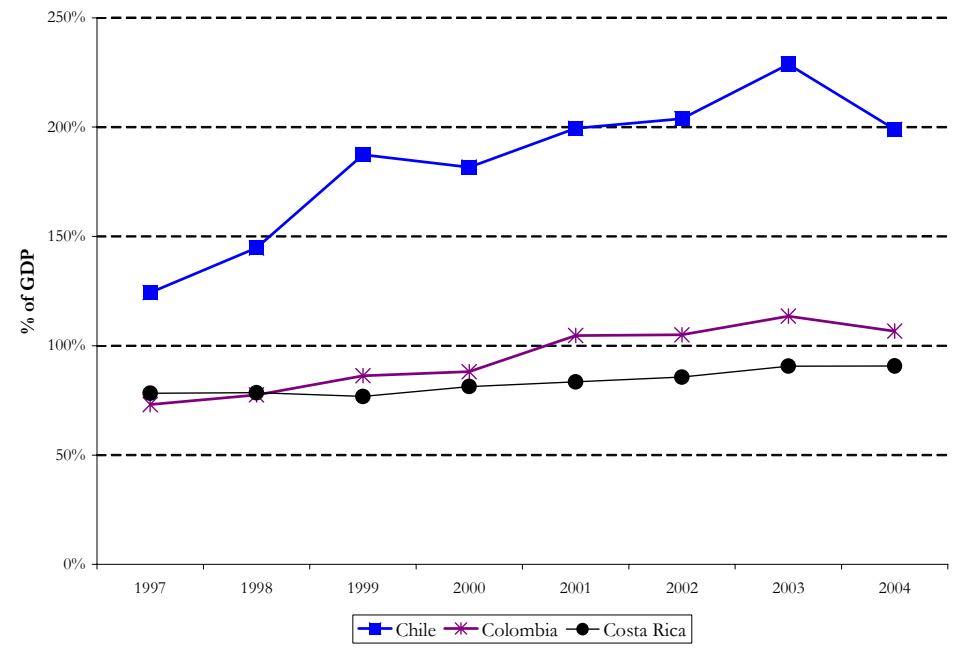

Source: Own analysis based on data from Lane P.R. and Milesi-Ferretti G.M. (March 2006).

Note: International financial integration is measured as the gross stock of a country's foreign assets and liabilities to GDP. 
Has actual liberalization been preferential in nature? In theory, liberalization commitments made under PTAs tend to be for the exclusive and preferential benefit of PTA partners. However, a review of the aforementioned PTAs and their rules of origin for financial services (especially those for Colombia and Costa Rica) suggest that the benefits of regional integration will not necessarily accrue solely to PTA counterparts (i.e. the US). While some real liberalization commitments - for example, the abolition of an economic needs test - are country-specific, most of them require new 'horizontal' regulations or laws that would presumably apply to the entire industry and could actually benefit financial established third country suppliers - for example, opening up Costa Rica's insurance market, or permitting branching and certain outsourcing services for collective investment schemes in Colombia. This would seem to suggest that there might not be important first-mover advantages or serious economic distortions created by using PTAs to promote market opening in financial services, although much depends on the specific nature of liberalization commitments per se.

Is a GATS- or NAFTA-type 'architectural' model preferable for liberalization purposes? As mentioned previously, the choice of modality used to schedule liberalization commitments can be an important contributor to the actual degree of liberalization attained. GATS- and NAFTA-type models both have their advantages and drawbacks, and can theoretically generate the same liberalization outcome. A simple review of the PTAs analyzed in this study would seem to favor the negative list approach and broader rules and disciplines embedded in NAFTA-type agreements on transparency grounds. However, this result can be largely attributed to the involvement of the US in such agreements, which tends to distort the results in favor of the NAFTA model. In addition, one could argue that the direction of causality between scheduling approaches and levels of liberalization commitments can run both ways - for example, a country with a very open financial system would feel more comfortable using a negative list approach (and vice versa). Finally, even some NAFTA-type agreements tend to use a hybrid lists for financial service commitments. For example, the US-Chile FTA comprised a positive list for commitments in insurance and insurance-related services and a negative list for commitments in banking and other financial services; a hybrid approach was also used for different supply modes. In fact, both models have introduced new features in recent years that borrow from each other, showing some signs of convergence around a more hybrid-type approach. 


\section{Conclusion}

A number of conclusions can be reached from the above analysis. First, the proliferation of PTAs in recent years, which is an on-going phenomenon with global proportions, has contributed to greater financial services liberalization commitments for many LCR countries and led to an increasingly complex regional 'commitments map' (or financial services 'spaghetti bowl'). Most progress in financial services rule-making and market opening - typically via a stand-alone financial services chapter - has been achieved via FTAs; by contrast, LCR countries that have relied on the multilateral framework and on sub-regional customs unions for trade commitments in financial services have not made much progress to-date.

Second, the inclusion of financial services in LCR PTAs depends greatly on whether it is a North-South or South-South agreement. As can be seen below in Table 4 , the main proponents of including financial services have been developed countries in North-South agreements. This is not surprising: most LCR countries are net importers of financial services, have few - if any - perceived 'offensive' interests linked to a "demandeur" or domestic constituency, both of which lessen the scope for striking reciprocal bargains within the sector. Conversely, the inclusion of financial services in most North-South agreements likely reflects the fact that the majority of foreign financial institutions in LCR countries are headquartered in developed countries, as well as the relative bargaining powers between the negotiating counterparts. Only two LCR countries have tended to include financial services chapters in South-South agreements Mexico (primarily in the immediate post-NAFTA period) and Panama (which is an offshore financial center and a net exporter of financial services). A more detailed comparison of financial services chapters under North-South and South-South PTAs, particularly when they involve the same country, would be an interesting follow-up research topic.

Table 4: Coverage of Financial Services (FS) by Type of FTA in LCR

\begin{tabular}{|c|c|c|}
\hline & North-South & South-South \\
\hline Inclusion of FS Chapter & 9 & 7 \\
\hline No FS Chapter & 4 & 14 \\
\hline
\end{tabular}

Source: Table 3.

Note: All LCR FTAs (including those not yet implemented), starting with NAFTA, have been categorized either as a North-South (i.e. including at least one developed country) or a South-South trade agreement.

Third, an analysis of a sample of LCR countries that have recently participated in PTAs yields evidence of significant additional liberalization commitments when compared to the GATS ${ }^{70}$. This is not unusual given the time elapsed and the (unilateral) market opening undertaken by these countries since the mid-1990s. Additional commitments tend to span all financial sub-sectors, including those that were not well

\footnotetext{
${ }^{70}$ Roy M., Marchetti J. and Hoe Lim A. (September 2006) undertake this analysis for a broader set of PTAs and sectors (as well as compare PTA commitments to recent WTO offers) and reach the same conclusion.
} 
covered in the first GATS round, such as insurance, securities-related and other financial services. The same is true in modal terms, with significant new commitments particularly in mode 2 (consumption abroad). Commitments are in general more extensive across all modes for FTAs involving the US, particularly for mode 2. By contrast, mode 1 commitments, while better than what has been harvested to date under the GATS, remain relatively more timid and are generally based on those found in the Understanding on Commitments in Financial Services.

Fourth, de novo liberalization - which has chiefly taken the form of precommitments to future market-opening - is relatively modest for the sample of LCR countries under review. Apart from Costa Rica's insurance sector, real liberalization appears to have mostly taken place in the cross-border provision of some insurance services, as well as in asset management and auxiliary financial services. Although there is limited available data on the actual market size of these sub-sectors and modes, anecdotal evidence suggests that they are relatively less important than 'core' banking services. However, the abolition of numerical quotas (e.g. economic needs test) and certain juridical restrictions on forms of entry (e.g. insurance branching ${ }^{71}$ ) might also contribute to further liberalization in other sub-sectors under mode 3.

The above finding is a strong indication that, with a few exceptions, PTAs are primarily used to consolidate and 'lock in' existing unilateral liberalization rather than as means to actively promote further market opening and the process of domestic regulatory reform. The fact that the LCR countries under review appear to have already largely liberalized their domestic financial systems on a unilateral basis prior to their engagement in PTA negotiations has also contributed to this outcome. In fact, there could well be an inverse relationship between de novo liberalization and a country's initial conditions in terms of actual market openness - as evidenced when comparing Chile and Costa Rica but this study's sample is too small to draw any firm conclusions. More work needs to be done in this area, both in terms of expanding the number of countries under review and in collecting relevant data on actual market size by sub-sector and mode, in order to fully confirm the above assertions.

Fifth, consolidation of the regulatory status quo and the application of certain disciplines in trade agreements remain important because they can limit the arbitrary use (and abuse) of 'policy space' by the authorities. New disciplines such as those on regulatory transparency, as well as the locking-in of the current policy regime via commitments, standstill and ratcheting clauses, enhance predictability, prevent potentially costly policy reversals, and can thus benefit both domestic and foreign financial services providers and local consumers. It is therefore conceivable that a PTA could exert significantly positive impact on the business environment (including for financial services) even if real liberalization commitments remain limited to the status quo. However, the issue of policy space is a double-edged sword, and policymakers need to decide on the level of policy flexibility and regulatory discretion (which might not be the current one) that properly balances policy considerations that go beyond trade

\footnotetext{
${ }^{71}$ However, it should be noted that domestic authorities retain the right to regulate such branches as they deem necessary for prudential purposes, including via the establishment of local capital requirements.
} 
liberalization objectives per se. Linked to this issue is the need for policymakers negotiating the financial services provisions of PTAs to be cognizant of the aforementioned important nuances in disciplines and commitments ${ }^{72}$ that might create unintended consequences or limit policy space beyond what was envisaged.

Sixth, many de novo liberalization commitments in FTAs are actually not preferential in nature. While some commitments are country-specific and benefit the financial services providers of the FTA counterpart, others require new 'horizontal' regulations or laws that would presumably apply to the entire industry and could actually benefit financial service providers from third countries. This would seem to suggest that there might not be important first-mover advantages or serious economic distortions created by using PTAs to promote market opening in financial services, although much depends on the specific nature of liberalization commitments per se. This somewhat counter-intuitive finding needs to be further corroborated by additional research.

Seventh, it is unclear whether GATS- or NAFTA-type 'architectural' models actually lead to greater liberalization in financial services. A simple review of the FTAs analyzed in this paper would seem to favor the negative list approach and broader rules and disciplines embedded in NAFTA-type agreements (the most widely used in LCR), primarily on grounds of heightened regulatory transparency, but this can be largely attributed to the involvement of the US in them. In addition, one could argue that the direction of causality between scheduling approaches and the level of liberalization commitments can run both ways. Finally, even NAFTA-type agreements have tended to use a hybrid list for financial service commitments - in fact, both models have introduced new features in recent years that borrow from each other, revealing signs of convergence around a more hybrid-type approach.

Finally, it is likely too early to judge the outcomes of PTAs on domestic financial systems and overall welfare in LCR countries. The lack of relevant data and analysis available to assess their ex post impact - or to support the decision-making process ex ante - remains an important constraint. However, even if a commonly accepted methodology for quantifying impact was established, the short time span since the negotiation or entry into force of PTAs under review means that their contribution whether anticipated or unanticipated - still cannot be fully assessed. In particular, financial services commitments and disciplines, including dispute settlement mechanisms, have not been put to the test during a market downturn or a significant revision of domestic financial system policy priorities, which is typically when constraints on 'policy space' kick in.

\footnotetext{
${ }^{72}$ These include, for example, the definition and coverage of financial services supplier versus (regulated) financial institution in NAFTA-type agreements; the relationship between financial services and other chapters; the denial of benefits clause, which is the trade in services-equivalent of rules of origin; restrictions on the imposition of capital controls or payments restrictions, which become particularly important in times of crisis; existence of ratcheting and/or standstill clauses; and the use of a negative list approach, with its concomitant need to include all reservations in an Appendix ("list it or lose it").
} 


\section{References}

Arbeláez, M. A., Flórez A. and Salazar N. (August 2006), "Financial Services in the Colombia-U.S. Free Trade Agreement”, World Bank mimeo.

Barth J., Marchetti J., Nolle D. and Sawangngoenyuang W. (October 2006), "Foreign Banking: Do Countries' WTO Commitments Match Actual Practice?”, WTO Economic Research and Statistics Division, Staff Working Paper ERSD-2006-11.

Bhagwati J. \& Panagariya A. (1997), "The Economics of Preferential Trade Agreements”, The American Enterprise Institute for Public Policy Research, AEI.

Bouzas R. and Soltz H. (December 2005), "Argentina and the GATS: A Study on the Domestic Determinants of GATS Commitments" in Gallagher P., Low P. and Stoler A. (eds.) Managing the Challenges of WTO Participation, WTO.

Claessens S. and Glaessner T. (April 1998), "The Internationalization of Financial Services in Asia”, World Bank Policy Research Working Paper 1911.

Claessens S. and Jansen M. eds. (2000), The Internationalization of Financial Services: Issues and Lessons for Developing Countries, The World Bank and WTO.

Claessens S. (July 2002), "Regulatory Reform and Trade Liberalization in Financial Services”, paper presented at the joint OECD-World Bank conference on Regulatory Reform and Trade Liberalization in Services.

Contreras P. and Yi S. (December 2003), “Internationalization of Financial Services in Asia-Pacific and the Western Hemisphere” Pacific Economic Cooperation Council working paper (December 2003).

Contreras P. (2005), "Liberalization of Trade in Financial Services: New Trends in the Western Hemisphere”, mimeo.

Cornford A. (June 2004), “The WTO Negotiations on Financial Services: Current Issues and Future Directions”, UNCTAD Discussion Paper No. 172.

Crawford J. and Fiorentino R. (2005), "The Changing Landscape of Regional Trade Agreements", WTO Discussion Paper 8.

De la Cruz J. and Stephanou C. (September 2006), "Financial System Structure in Colombia: A Proposal for a Reform Agenda”, World Bank Policy Research Working Paper 4006.

Dobson W. and Jacquet P. (June 1998), Financial Services Liberalization in the WTO, Institute for International Economics.

Dobson W. (August 2002), “Further Financial Liberalization in the Doha Round?”, Institute for International Economics Policy Brief No. PB02-8.

Dobson W. (April 2004), "Financial Services and International Trade Agreements: the Development Dimension”, World Bank Institute note.

Echandi R. (2006), "The DR-CAFTA-US FTA Negotiations in Financial Services: The Experience of Costa Rica", World Bank mimeo.

Fink C. and Nikomborirak D. (forthcoming), "Rules of Origin in Services: A Case Study of Five ASEAN Countries" in Trade in Services: New Perspectives on Liberalization, Regulation, and Development edited by Panizzon M., Pohl N. and Sauvé P. (Cambridge: Cambridge University Press).

Gary G. (summer 2004), "Free Circulation of Services in Mercosur: A Pending Task, Law and Business Review of the Americas Volume X No. 3. 
Gary G. (October 2006), "In Search of a Strategy for the Liberalization of Trade in Services in MERCOSUR", to be presented at the Fourth Annual Conference of the Euro-Latin Study Network on Integration and Trade - IADB, Paris.

Harms P., Mattoo A. and Schuknecht L. (March 2003), "Explaining Liberalization Commitments in Financial Services Trade", World Bank Policy Research Working Paper 2999.

Hoekman B., Mattoo A. and English P. eds. (2002), Development, Trade, and the WTO, The World Bank.

Hoekman B. (October 2006), "Liberalizing Trade in Services: A Survey”, World Bank Policy Research Working Paper 4030.

Johnston B. (July 1998), "Sequencing Capital Account Liberalizations and Financial Sector Reform”, IMF Paper on Policy Analysis and Assessment 98/8.

Kaminsky G. and Schmukler S. (February 2003), "Short Run Pain, Long Run Gain: The Effects of Financial Liberalization”, IMF Working Paper.

Key S. (1997), "Financial Services in the Uruguay Round and the WTO”, Occasional Paper 54, Group of Thirty.

Key S. (2003), The Doha Round and Financial Services Negotiations, American Enterprise Institute.

Kireyev A. (August 2002), "Liberalization of Trade in Financial Services and Financial Sector Stability (Analytical Approach)”, IMF Working Paper 02/138.

Kono M., Low P., Luanga M., Mattoo A., Oshikawa M. And Schuknecht L. (1997), "Opening Markets in Financial Services and the Role of the GATS", WTO Secretariat Special Study.

Kono M. and Schuknecht L. (November 1998), "Financial Services Trade, Capital Flows and Financial Stability”, WTO Staff Working Paper 98-12.

Kose A. M., Prasad E., Rogoff K. and Wei S. (August 2006), "Financial Globalization: A Reappraisal”, IMF Working Paper 06/189.

Lane P.R. and Milesi-Ferretti G.M. (March 2006), "The External Wealth of Nations Mark II: Revised and Extended Estimates of Foreign Assets and Liabilities, 1970-2004", IMF Working Paper 06/69.

Lehmann A., Tamirisa N. and Wieczorek J. (December 2003), "International Trade in Services: Implications for the IMF", IMF Policy Discussion Paper 03/6.

Marchetti J. (September 2004), "Developing Countries in the WTO Services Negotiations", WTO Economic Research and Statistics Division, Staff Working Paper ERSD-2004-06.

Marconini M. (May 2006), "Services in Regional Agreements between Latin American and developed countries", CEPAL - Serie Comercio internacional.

Mattoo A. (September 1999), "Financial Services and the World Trade Organization: Liberalization Commitments of the Developing and Transition Economies", World Bank Policy Research Working Paper 2184.

Matoo A., Rathindran R. and Subramanian A. (August 2001), "Measuring Services Trade Liberalization and its Impact on Economic Growth: An Illustration", World Bank Policy Research Working Paper 2655.

Mattoo A. and Sauvé P. eds. (August 2003), Domestic Regulation \& Service Trade Liberalization, The World Bank and Oxford University Press. 
Norton J. and Baquero-Herrera M. (September 2005), "Financial Services in the FTAA Area: Sifting Through the 'Spaghetti Bowl' of Existing and Divergent Treaty Arrangements and Approaches Within the Western Hemisphere - The Need for a Viable Convergence Process", Law and Business Review of the Americas.

OECD (March 2000), "Cross-Border Trade in Financial Services: Economics and Regulation”, Financial Market Trends No. 75.

OECD (November 2003), "Managing Request-Offer Negotiations under the GATS: The Case of Insurance Services", Working Party of the Trade Committee.

Roy M., Marchetti J. and Hoe Lim A. (September 2006), "Services Liberalization in the New Generation of Preferential Trade Agreements (PTAs): How Much Further than the GATS?", WTO Economic Research and Statistics Division, Staff Working Paper ERSD-2006-07.

Saez S. (2005), "Trade Policy Making in Latin America: a Compared Analysis”, CEPAL. Saez R. (2006), “Trade in Financial Services: The Case of Chile”, World Bank mimeo.

Salazar-Xirinachs J.M. (October 2002), "Proliferation of Sub-Regional Trade Agreements in the Americas: An Assessment of Key Analytical and Policy Issues", OAS Trade Unit Studies.

Sauvé P. and Steinfatt K. (2001), "Financial Services and the WTO: What Next?", Brookings Institution.

Sauvé P. (forthcoming), "Adding value at the Periphery: Aiming for GATS+ Advances in Regional Trade Agreements on Services”, World Trade Review.

Sauvé P. and Beviglia-Zampetti A. (2006), "Rules of Origin for Services: A Review of Current Practice", in Estevadeordal A. et al., eds., The Origin of Goods, London: Oxford University Press and CEPR.

Stephenson S. (2002), "Can Regional Liberalization of Services go Further than Multilateral Liberalization under the GATS?”, World Trade Review.

Stephenson S. (June 2005), "Regionalism in Latin America”, presentation in World Bank course on "Regionalism in Developing Countries: Issues and Implications".

Tamirisa N., Sorsa P., Bannister G., McDonald B. and Wieczorek J. (February 2000), "Trade Policy in Financial Services", IMF Working Paper 00/31.

The World Bank (2005), Global Economic Prospects: Trade, Regionalism and Development report.

Valckx N. (October 2002), "WTO Financial Services Liberalization: Measurement, Choice and Impact on Financial Stability", De Nederlandsche Bank Research Department, Research Memorandum WO no 705/0227.

Valckx N. (December 2002), "WTO Financial Services Commitments: Determinants and Impact on Financial Stability”, IMF Working Paper 02/214.

Van Horen N. (May 2006), "Foreign Banking in Developing Countries: Origin Matters", World Bank mimeo.

Wagner C. (Winter 1999), "The New WTO Agreement on Financial Services and Chapter 14 of NAFTA: Has Free Trade in Banking Finally Arrived?”, NAFTA: Law and Business Review of the Americas.

World Trade Organization (December 1998), "Financial Services: Background Note by the Secretariat", mimeo.

World Trade Organization (March 2006), "The General Agreement on Trade in Services: An Introduction", mimeo. 


\section{Appendix I: GATS Definition of Financial Services}

\section{Article 5 of the Annex on Financial Services}

a) A financial service is any service of a financial nature offered by a financial service supplier of a Member. Financial services include all insurance and insurance-related services, and all banking and other financial services (excluding insurance). Financial services include the following activities:

Insurance and insurance-related services

i. Direct insurance (including co-insurance)

A. Life

B. Non-life

ii. Reinsurance and retrocession

iii. Insurance intermediation, such as brokerage and agency

iv. Services auxiliary to insurance, such as consultancy, actuarial, risk assessment and claim settlement services

Banking and other financial services (excluding insurance)

v. Acceptance of deposits and other repayable funds from the public

vi. Lending of all types, including consumer credit, mortgage credit, factoring and financing of commercial transactions

vii. Financial leasing

viii. All payment and money transmission services, including credit, charge and debit cards, travelers cheques and bankers drafts

ix. Guarantees and commitments

x. Trading for own account or for account of customers, whether on an exchange, in an over-the-counter market or otherwise, the following:

A. Money market instruments (including cheques, bills, certificates of deposits)

B. Foreign exchange

C. Derivative products including, but not limited to, futures and options

D. Exchange rate and interest rate instruments, including products such as swaps, forward rate agreements

E. Transferable securities

F. Other negotiable instruments and financial assets, including bullion

xi. Participation in issues of all kinds of securities, including underwriting and placement as agent (whether public or privately) and provision of services related to such issues

xii. Money broking 
xiii. Asset management, such as cash or portfolio management, all forms of collective investment management, pension fund management, custodial, depository and trust services

xiv. Settlement and clearing service for financial assets, including securities, derivative products, and other negotiable instruments

xv. Provision and transfer of financial information, and financial data processing and related software by suppliers of other financial services

xvi. Advisory, intermediation and other auxiliary financial services on all the activities listed in subparagraphs $\mathrm{v}$ ) through $\mathrm{xv}$ ), including credit reference and analysis, investment and portfolio research and advice, advice on acquisitions and on corporate restructuring and strategy.

b) A financial service supplier means any natural or juridical person of a Member wishing to supply or supplying financial services but the term "financial service supplier" does not include a public entity.

c) "Public entity" means:

i. A government, a central bank or a monetary authority, of a Member, or an entity owned or controlled by a Member, that is principally engaged in carrying out governmental functions or activities for governmental purposes, not including an entity principally engaged in supplying financial services on commercial terms.

ii. Or a private entity, performing functions normally performed by a central bank or monetary authority, when exercising those functions. 


\section{Appendix II: Liberalization Commitments in Financial Services for Selected LCR Countries}

\section{Table II-1: Chile - Financial Services Trade Liberalization Commitments}

\begin{tabular}{|c|c|c|c|c|c|c|}
\hline \multirow{3}{*}{ SECTOR } & \multirow{2}{*}{\multicolumn{2}{|c|}{$\begin{array}{l}\text { MAIN COMMITMENTS UNDER GATS } \\
\text { (1999) }\end{array}$}} & \multicolumn{4}{|c|}{ IMPROVEMENT IN COMMITMENTS COMPARED TO THE GATS } \\
\hline & & & \multicolumn{2}{|c|}{ US-CHILE FTA (2004) } & \multicolumn{2}{|c|}{ EC-CHILE FTA (2003) } \\
\hline & Market Access & National Treatment & Market Access & National Treatment & Market Access & National Treatment \\
\hline \multicolumn{7}{|c|}{ HORIZONTAL (only those most relevant for financial services) } \\
\hline $\begin{array}{l}\text { All Sectors } \\
\text { / Financial } \\
\text { Services }\end{array}$ & $\begin{array}{l}\text { (3): limitations on juridical } \\
\text { form of establishment and } \\
\text { authorization criteria (this } \\
\text { includes an economic needs } \\
\text { test for financial services } \\
\text { suppliers) } \\
\text { (4): no commitments, except } \\
\text { for transfers of natural } \\
\text { persons related to (3) and } \\
\text { subject to various criteria }\end{array}$ & $\begin{array}{l}\text { (3): foreign investors } \\
\text { may transfer abroad } \\
\text { their capital after } 3 \\
\text { years from entry*; at } \\
\text { least } 85 \% \text { of staff } \\
\text { employed locally by } \\
\text { enterprises with more } \\
\text { than } 15 \text { employees must } \\
\text { be Chilean } \\
\text { (4): no commitments, } \\
\text { except for natural } \\
\text { persons listed in market } \\
\text { access }\end{array}$ & $\begin{array}{l}\text { (3) lifting of numerical restrictions } \\
\text { (including an economic needs test) on } \\
\text { establishment of financial institutions } \\
\text { (including mandatory pension funds); } \\
\text { some juridical form restrictions on } \\
\text { financial institutions that are mandated by } \\
\text { existing legislation are also removed (see } \\
\text { below) }\end{array}$ & $\begin{array}{l}\text { (3): at least } 85 \% \text { of staff employed } \\
\text { locally by enterprises with more } \\
\text { than } 25 \text { employees must be } \\
\text { Chilean }\end{array}$ & $\begin{array}{l}\text { (3): no economic needs test } \\
\text { for suppliers in financial } \\
\text { services sub-sectors where } \\
\text { commitments were made }\end{array}$ & $\begin{array}{l}\text { (3): at least } 85 \% \text { of staff } \\
\text { employed locally by } \\
\text { enterprises with more } \\
\text { than } 25 \text { employees must } \\
\text { be Chilean }\end{array}$ \\
\hline \multicolumn{7}{|c|}{ FINANCIAL SERVICES-SPECIFIC } \\
\hline $\begin{array}{c}\text { Insurance } \\
\text { and } \\
\text { Insurance- } \\
\text { Related } \\
\text { Services }\end{array}$ & $\begin{array}{l}\text { (1): no commitments except } \\
\text { for foreign reinsurance } \\
\text { providers (including } \\
\text { brokers), subject to } \\
\text { enrollment with, and } \\
\text { requirements of, domestic } \\
\text { supervisor } \\
\text { (2): no commitments } \\
\text { (3): liberalization of direct } \\
\text { life and non-life insurance } \\
\text { and of reinsurance and } \\
\text { retrocession (including } \\
\text { brokerage) subject to } \\
\text { restrictions on form of } \\
\text { establishment and on } \\
\text { enrollment with domestic } \\
\text { supervisor } \\
\text { (4): only commitments of } \\
\text { horizontal schedule }\end{array}$ & $\begin{array}{l}\text { (1): same as for market } \\
\text { access except that } \\
\text { reinsurance premiums } \\
\text { are subject to tax of } 6 \% \\
\text { (2): no commitments } \\
\text { (3): same as for market } \\
\text { access } \\
\text { (4): only commitments } \\
\text { of horizontal schedule }\end{array}$ & $\begin{array}{l}\text { (1): liberalization of sale and brokerage of } \\
\text { MAT insurance (no later than one year } \\
\text { after entry into force of agreement) and } \\
\text { consultancy, actuarial and risk assessment } \\
\text { services } \\
\text { (2):liberalization of all insurance and } \\
\text { insurance-related services except } \\
\text { mandatory insurance services or those } \\
\text { related to the social security system } \\
\text { (3): liberalization of insurance branching } \\
\text { (no later than } 4 \text { years after entry into } \\
\text { force of agreement) subject to regulation, } \\
\text { and of services auxiliary to insurance }\end{array}$ & $\begin{array}{l}\text { (1): same as for market access } \\
\text { (2): same as for market access } \\
\text { (3): no more than a minority of the } \\
\text { Board of Directors of a US-owned } \\
\text { financial institution may be } \\
\text { composed of Chilean nationals } \\
\text { and/or residents (except for } \\
\text { insurance brokerage and claims } \\
\text { settlement) }\end{array}$ & $\begin{array}{l}\text { (1) + (2): liberalization of } \\
\text { sale and brokerage of } \\
\text { MAT (one year after entry } \\
\text { into force of agreement) } \\
\text { subject to supervision in } \\
\text { the country of origin } \\
\text { (3): liberalization of sale } \\
\text { and brokerage of MAT } \\
\text { (subject to enrollment } \\
\text { with, and requirements of, } \\
\text { domestic supervisor), } \\
\text { voluntary pension savings } \\
\text { plans by life insurance } \\
\text { companies (as of } 3 / 1 / 2005 \text { ) } \\
\text { subject to supervisory } \\
\text { authorization, and of claim } \\
\text { settlement and auxiliary } \\
\text { insurance services }\end{array}$ & $\begin{array}{l}(1)+(2) \text { : same as for } \\
\text { market access } \\
\text { (3): same as for market } \\
\text { access }\end{array}$ \\
\hline
\end{tabular}




\begin{tabular}{|c|c|c|c|c|c|c|}
\hline $\begin{array}{l}\text { Banking } \\
\text { and Other } \\
\text { Financial } \\
\text { Services }\end{array}$ & $\begin{array}{l}\text { (3): liberalization of } \\
\text { acceptance of deposits, } \\
\text { lending (except factoring), } \\
\text { financial leasing, issue and } \\
\text { operation of credit cards, } \\
\text { guarantees and } \\
\text { commitments, participation } \\
\text { and custody of securities, } \\
\text { some advisory, } \\
\text { intermediation and other } \\
\text { auxiliary financial services, } \\
\text { and asset management } \\
\text { (except for collective } \\
\text { investment schemes and } \\
\text { pension funds), subject to } \\
\text { restrictions on form of } \\
\text { establishment, transfer of } \\
\text { control and on operations } \\
\text { (particularly for non-bank } \\
\text { securities services providers) } \\
\text { (4): only commitments of } \\
\text { horizontal schedule }\end{array}$ & $\begin{array}{l}\text { (3): same as for market } \\
\text { access } \\
\text { (4): only commitments } \\
\text { of horizontal schedule }\end{array}$ & $\begin{array}{l}(1)+(2)+(4) \text { : liberalization of provision } \\
\text { and transfer of financial information, } \\
\text { financial data processing (subject to prior } \\
\text { authorization as required), advisory } \\
\text { (subject to regulatory and registration } \\
\text { requirements as required) and other } \\
\text { auxiliary financial services except } \\
\text { intermediation and credit reference and } \\
\text { analysis (the latter service can be } \\
\text { provided in the future) } \\
\text { (1): liberalization of investment advice } \\
\text { and portfolio management services } \\
\text { (excluding custodial and trustee services) } \\
\text { by financial institutions (except trust } \\
\text { companies) for domestic collective } \\
\text { investment schemes when they invest in } \\
\text { securities traded abroad } \\
\text { (2): liberalization of all banking and other } \\
\text { financial services } \\
\text { (3): liberalization of factoring, all } \\
\text { payment and money transmission } \\
\text { services, trading, money broking, } \\
\text { management of collective investment } \\
\text { schemes (subject to regulations on form } \\
\text { of establishment), voluntary pension } \\
\text { savings plans (as of 3/1/2005), settlement } \\
\text { and clearing services, financial } \\
\text { information transfer and data processing, } \\
\text { and all advisory, intermediation and other } \\
\text { auxiliary services }\end{array}$ & $\begin{array}{l}(1)+(2)+(4) \text { : same as for market } \\
\text { access } \\
(1)+(3) \text { : same as for market } \\
\text { access } \\
(2) \text { : same as for market access } \\
\text { (3): same as for market access; no } \\
\text { more than a minority of the Board } \\
\text { of Directors of a US-owned } \\
\text { financial institution (except } \\
\text { stockbrokers and securities agents) } \\
\text { may be composed of Chilean } \\
\text { nationals and/or residents; NT for } \\
\text { US investors in mandatory pension } \\
\text { funds }\end{array}$ & $\begin{array}{l}\text { (3) liberalization of } \\
\text { voluntary pension savings } \\
\text { plans (as of 3/1/2005) } \\
\text { subject to supervisory } \\
\text { authorization, banking- } \\
\text { related advisory and other } \\
\text { auxiliary services, } \\
\text { provision and transfer of } \\
\text { financial information and } \\
\text { data processing, securities } \\
\text { risk rating activities subject } \\
\text { to supervisory } \\
\text { authorization, and various } \\
\text { trading operations and fund } \\
\text { management activities by } \\
\text { non-bank securities } \\
\text { services providers }\end{array}$ & $\begin{array}{l}\text { (3) same as for market } \\
\text { access; NT for factoring }\end{array}$ \\
\hline
\end{tabular}

Source: Authors' interpretation based on WTO and USTR information, Contreras P. and Yi S. (December 2003), Contreras P. (2005) and Saez R. (2006).

Note: (1) - (4) above refers to the 4 modes of supply. The Table does not include other disciplines or provisions on payments and capital movements. MAT refers

to international maritime transport, international commercial aviation and goods in international transit. NT refers to National Treatment.

* The limitation is 2 years in the case of foreign investors who participate in the financial services sector. 
Table II-2: Colombia - Financial Services Trade Liberalization Commitments

\begin{tabular}{|c|c|c|c|c|}
\hline \multirow{2}{*}{ SECTOR } & \multicolumn{2}{|c|}{ MAIN COMMITMENTS UNDER GATS (1997) } & \multicolumn{2}{|c|}{ IMPROVEMENT IN COMMITMENTS UNDER US-COLOMBIA FTA } \\
\hline & Market Access & National Treatment & Market Access & National Treatment \\
\hline \multicolumn{5}{|c|}{ HORIZONTAL (only those most relevant for financial services) } \\
\hline $\begin{array}{l}\text { All Sectors } \\
\text { / Financial } \\
\text { Services }\end{array}$ & $\begin{array}{l}\text { (3): economic needs test might be required } \\
\text { for domestic and foreign financial entities; } \\
\text { limitations on juridical form of } \\
\text { establishment; supply of financial services } \\
\text { requires prior government authorization } \\
\text { and is subject to relevant regulations } \\
\text { (4): no commitments except for natural } \\
\text { persons who are managers, legal } \\
\text { representatives or technical specialists }\end{array}$ & $\begin{array}{l}\text { (3): special conditions on privatization of } \\
\text { state-owned entities shall be exclusively } \\
\text { offered to Colombian nationals; at least } \\
80 \% \text { and } 90 \% \text { of ordinary and specialist } \\
\text { staff respectively, which is employed } \\
\text { locally by enterprises with more than } 10 \\
\text { employees, must be Colombian } \\
\text { (4): no commitments except for natural } \\
\text { persons listed in market access }\end{array}$ & $\begin{array}{l}\text { (3): lifting of numerical restrictions and of an economic needs test on establishment } \\
\text { of financial institutions (including mandatory pension funds); some juridical form } \\
\text { restrictions on financial institutions that are mandated by existing legislation are also } \\
\text { removed (see below) }\end{array}$ & $\begin{array}{l}\text { (1): foreign investors may make portfolio } \\
\text { investments in securities only through a } \\
\text { foreign capital investment fund } \\
\text { (3): no more than a minority of the Board of } \\
\text { Directors of a foreign-owned financial } \\
\text { institution may be composed of nationals } \\
\text { and/or residents }\end{array}$ \\
\hline \multicolumn{5}{|c|}{ FINANCIAL SERVICES-SPECIFIC } \\
\hline $\begin{array}{l}\text { Insurance } \\
\text { and } \\
\text { Insurance- } \\
\text { Related } \\
\text { Services }\end{array}$ & $\begin{array}{l}\text { (1): liberalization of reinsurance and } \\
\text { retrocession, and of direct insurance } \\
\text { concerning foreign trade operations } \\
\text { (2): no commitments } \\
\text { (3): liberalization of all insurance and } \\
\text { insurance-related services except life } \\
\text { insurance } \\
\text { (4): only commitments of horizontal } \\
\text { schedule }\end{array}$ & $\begin{array}{l}\text { (1): NT for reinsurance and retrocession } \\
\text { (2): no commitments } \\
\text { (3): NT for all insurance and insurance- } \\
\text { related services } \\
\text { (4): only commitments of horizontal } \\
\text { schedule }\end{array}$ & $\begin{array}{l}\text { (1) + (4): liberalization of sale and brokerage of MAT and space launching and } \\
\text { freight insurance subject to registration requirements (no later than four years after } \\
\text { entry into force of agreement), sale and brokerage of reinsurance and retrocession, } \\
\text { and sale of services auxiliary to insurance } \\
\text { (2): liberalization of all insurance and insurance-related services except mandatory } \\
\text { insurance services or those related to the social security system or when the policy } \\
\text { holder, insured or beneficiary is a State entity (no later than four years after entry } \\
\text { into force of agreement); } \\
\text { (3): establishment of insurance branches subject to regulatory requirements (no later } \\
\text { than four years after entry into force of agreement); liberalization of life insurance }\end{array}$ & $\begin{array}{l}(1)+(4) \text { : same as for market access except } \\
\text { a foreign national resident in Colombia for } \\
\text { less than one year may not supply insurance } \\
\text { agency services } \\
\text { (2): same as for market access } \\
\text { (3): same as for market access }\end{array}$ \\
\hline $\begin{array}{l}\text { Banking } \\
\text { and Other } \\
\text { Financial } \\
\text { Services }\end{array}$ & $\begin{array}{l}\text { (1): no commitments } \\
\text { (2): no commitments } \\
\text { (3): liberalization of all banking and other } \\
\text { financial services except asset } \\
\text { management, payment and money } \\
\text { transmission services, settlement and } \\
\text { clearing services for financial assets, and } \\
\text { trading for own account or for account of } \\
\text { customers of money market instruments, } \\
\text { foreign exchange, and exchange and } \\
\text { interest rate instruments } \\
\text { (4): only commitments of horizontal } \\
\text { schedule }\end{array}$ & $\begin{array}{l}\text { (1): no commitments } \\
\text { (2): no commitments } \\
\text { (3): same as for market access } \\
\text { (4): only commitments of horizontal } \\
\text { schedule }\end{array}$ & $\begin{array}{l}\text { (1) + (2) + (4): liberalization of provision and transfer of financial information, } \\
\text { financial data processing, and of advisory and other auxiliary financial services } \\
\text { except intermediation and credit reference and analysis (the latter service may be } \\
\text { provided in the future) } \\
\text { (1) + (3): liberalization of investment advice and portfolio management services } \\
\text { (excluding custodial and trustee services) by financial institutions for domestic } \\
\text { collective investment schemes subject to registration requirements (no later than four } \\
\text { years after entry into force of agreement) } \\
\text { (2): liberalization of all banking and other financial services subject to registration } \\
\text { requirements (no later than four years after entry into force of agreement) } \\
\text { (3): establishment of bank branches subject to regulatory requirements; liberalization } \\
\text { of investment advice and portfolio management services (including execution and } \\
\text { custodial services for foreign investments) by financial institutions for domestic } \\
\text { mandatory pension funds subject to regulatory requirements (all of the above no later } \\
\text { than four years after entry into force of agreement), and of all remaining banking and } \\
\text { other financial services not already covered in the GATS }\end{array}$ & $\begin{array}{l}(1)+(2)+(4) \text { : same as for market access } \\
(1)+(3) \text { : same as for market access } \\
\text { (2): same as for market access } \\
\text { (3): same as for market access }\end{array}$ \\
\hline
\end{tabular}

Source: Authors' interpretation based on WTO and USTR information, Arbeláez M. A., Flórez A. and Salazar N. (August 2006).

Note: (1) - (4) above refers to the 4 modes of supply. The Table does not include other disciplines or provisions on payments and capital movements. MAT refers

to international maritime transport, international commercial aviation and goods in international transit. NT refers to National Treatment. 
Table II-3: Costa Rica - Financial Services Trade Liberalization Commitments

\begin{tabular}{|c|c|c|c|c|}
\hline \multirow{2}{*}{ SECTOR } & \multicolumn{2}{|c|}{ MAIN COMMITMENTS UNDER GATS (1997) } & \multicolumn{2}{|l|}{ IMPROVEMENT IN COMMITMENTS UNDER DR-CAFTA } \\
\hline & Market Access & National Treatment & Market Access & National Treatment \\
\hline \multicolumn{5}{|c|}{ HORIZONTAL (only those most relevant for financial services) } \\
\hline $\begin{array}{l}\text { All Sectors } \\
\text { / Financial } \\
\text { Services }\end{array}$ & $\begin{array}{l}\text { (3): Limitations on juridical form of } \\
\text { establishment for financial services providers } \\
\text { (4): no commitments except for entry and } \\
\text { temporary stay of (at most two) senior } \\
\text { executives and supervisors of an enterprise }\end{array}$ & $\begin{array}{l}\text { (4): same as for market } \\
\text { access }\end{array}$ & & $\begin{array}{l}\text { (3): no more than a } \\
\text { minority of the Board of } \\
\text { Directors of a foreign- } \\
\text { owned financial } \\
\text { institution may be } \\
\text { composed of nationals } \\
\text { and/or residents } \\
\end{array}$ \\
\hline \multicolumn{5}{|c|}{ FINANCIAL SERVICES-SPECIFIC } \\
\hline $\begin{array}{l}\text { Insurance } \\
\text { and } \\
\text { Insurance- } \\
\text { Related } \\
\text { Services }\end{array}$ & $(1)+(2)+(3)+(4):$ no commitments & $\begin{array}{l}(1)+(2)+(3)+(4): \text { no } \\
\text { commitments }\end{array}$ & $\begin{array}{l}\text { (1): liberalization of sale and intermediation of MAT and space launching and freight } \\
\text { insurance, sale and intermediation of reinsurance and retrocession, sale and intermediation of } \\
\text { services necessary to support global accounts (for multinationals), and sale of services } \\
\text { auxiliary to aforementioned insurance lines (no later than date of entry into force of the } \\
\text { agreement); liberalization of all remaining insurance intermediation and services auxiliary to } \\
\text { insurance, and of surplus lines* (no later than July 2007) } \\
\text { (3) establishment of insurance rep offices (no later than July 2007); liberalization of all } \\
\text { insurance and insurance-related services (no later than January 2008) except compulsory auto } \\
\text { and occupational risk insurance (to be liberalized no later than January 2011) and social } \\
\text { security-related insurance services } \\
\text { (4): liberalization of all insurance and insurance-related services (except compulsory auto, } \\
\text { occupational risk and social security-related insurance services) subject to registration } \\
\text { requirements }\end{array}$ & $\begin{array}{l}\text { (1): same as for market } \\
\text { access } \\
\text { (3) same as for market } \\
\text { access } \\
\text { (4): same as for market } \\
\text { access }\end{array}$ \\
\hline $\begin{array}{l}\text { Banking } \\
\text { and Other } \\
\text { Financial } \\
\text { Services }\end{array}$ & $\begin{array}{l}\text { (1) + (2): liberalization of provision and } \\
\text { transfer of financial information and financial } \\
\text { data processing } \\
\text { (3): liberalization of acceptance of deposits, } \\
\text { lending of all types, financial leasing (except } \\
\text { for commercial banks and non-bank financial } \\
\text { companies that are legally prohibited to } \\
\text { undertake this activity), credit card services, } \\
\text { provision and transfer of financial } \\
\text { information and financial data processing } \\
\text { (4): only commitments of horizontal } \\
\text { schedule }\end{array}$ & $\begin{array}{l}(1)+(2) \text { : same as for } \\
\text { market access } \\
\text { (3): same as for market } \\
\text { access } \\
\text { (4): only commitments } \\
\text { of horizontal schedule }\end{array}$ & $\begin{array}{l}\text { (1): liberalization of investment advice and portfolio management services (excluding } \\
\text { custodial and trustee services) by foreign financial institutions (except trust companies) for } \\
\text { domestic collective investment schemes (which includes mandatory and voluntary pension } \\
\text { funds) subject to registration requirements } \\
\text { (1)+ (4): liberalization of advisory and other auxiliary financial services excluding } \\
\text { intermediation } \\
\text { (2): liberalization of all banking and other financial services subject to registration } \\
\text { requirements } \\
\text { (3): liberalization of all remaining banking and other financial services not already covered in } \\
\text { the GATS } \\
\text { (4): liberalization of provision and transfer of financial information and financial data } \\
\text { processing }\end{array}$ & $\begin{array}{l}\text { (1): same as for market } \\
\text { access } \\
(1)+(4) \text { : same as for } \\
\text { market access } \\
\text { (2): same as for market } \\
\text { access } \\
\text { (3): same as for market } \\
\text { access } \\
\text { (4): same as for market } \\
\text { access }\end{array}$ \\
\hline
\end{tabular}

Source: Authors' interpretation based on WTO and USTR information, Echandi R. (2006).

Note: (1) - (4) above refers to the 4 modes of supply. The Table does not include other disciplines or provisions on payments and capital movements. MAT refers

to international maritime transport, international commercial aviation and goods in international transit. NT refers to National Treatment.

* Surplus lines are defined (as of January 2008) as" insurance coverage not available from an admitted company in the regular market". 